\title{
Transactions
}

\section{The synthesis and characterisation of novel ferrocenyl polyphenylenes $\uparrow$}

\author{
Dilwyn J. Roberts, ${ }^{a}$ Deanne Nolan, ${ }^{a}$ Gearóid M. Ó Máille, ${ }^{a}$ Graeme W. Watson, ${ }^{a}$ Anu Singh, ${ }^{b}$ \\ Isabelle Ledoux-Rak ${ }^{b}$ and Sylvia M. Draper*a
}

Received 6th March 2012, Accepted 20th May 2012
DOI: 10.1039/c2dt30542a

This work describes the synthesis and characterisation of a new series of polyphenylenes with up to four ferrocenyl moieties. The synthetic route involves the preparation of a number of novel precursors. Cyclopentadienones, generated from the two-fold Knoevenagel condensation of di-ferrocenyl propanones and diketones, are used in [2+4] Diels-Alder cycloadditions with appropriately substituted acetylenes. 13 is amongst the compounds isolated. It is the largest ferrocenyl-supported polyaromatic hydrocarbon (PAH) to date. Prepared via a Sonogashira cross-coupling reaction between ethynyl-Fc and iodo-HBC, it comprises a hexa-peri-hexabenzocoronene (HBC) core linked via acetylene to a ferrocenyl unit (Fc). The electrochemical and absorption properties of the ferrocenyl-polyphenylenes and the fully conjugated 13 are discussed. The NLO data for 13, determined by hyper Rayleigh scattering techniques, are compared to those of similar fulleryl-based compounds in the literature.

\section{Introduction}

As a robust organometallic electron-donor group with wellestablished substitution chemistry ${ }^{1}$ the ferrocenyl-moiety has been incorporated into new molecular materials exhibiting nonlinear optical (NLO) ${ }^{2}$ and ferromagnetic properties. ${ }^{3}$ The bulk properties of a molecular material can be heavily influenced in the solid-state by its packing arrangement. For this reason, compounds combining a ferrocene donor and a planar polycyclic aromatic hydrocarbon (PAH), capable of $\pi$-stacking, are of considerable interest. PAHs are useful as linking groups in donoracceptor organometallic systems because they are planar, relatively rigid with a fixed geometry and have various isomeric positions through which organometallic moieties may be bound. Their highly delocalised $\pi$-systems with small HOMO-LUMO energy separations and low vacant $\pi^{*}$-orbitals can facilitate electronic communication between donors and acceptors. Although large polycyclic materials incorporating over 200 carbon atoms have been characterised, very few of these systems are organometallic. Known examples include Bunz's cobalt-containing

\footnotetext{
${ }^{a}$ School of Chemistry, University of Dublin, Trinity College, College Green, Dublin 2, Ireland. E-mail: smdraper@tcd.ie;

Fax: +353-1-671-2826; Tel: +353-1-896-2026

${ }^{b}$ Laboratoire de Photonique Quantique et Moléculaire (UMR CNRS 8537), Institut d'Alembert, ENS Cachan, 61 Avenue du Président Wilson, 94235 Cachan, Cedex, France

$\dagger$ Electronic supplementary information (ESI) available: ${ }^{1} \mathrm{H}$ NMR (400 MHz) spectra recorded in $\mathrm{CDCl}_{3}$ of $4,7,8,9,10,11,12$, iodo-HBC and 1,2-bis ( $p$-ferrocenylphenyl)acetylene. The experimental $(+)$-MALDI-TOF spectra of $\mathbf{1 3}$ and $(\mathrm{MH})^{+}$simulated isotopic distribution pattern. Schematic and experimental details for the total synthesis of 1,2-bis( $p$-ferrocenylphenyl)acetylene. Tabulated electronic charge of the ethyne, cyclopentadienyl $(\mathrm{Cp})$, ferrocence and $\mathrm{HBC}$ components, ethynyl ferrocene and methyl derivative of 13 . See DOI: $10.1039 / \mathrm{c} 2 \mathrm{dt} 30542 \mathrm{a}$
}

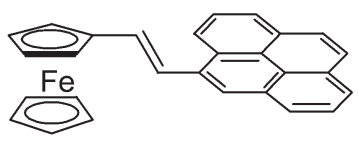

(I)

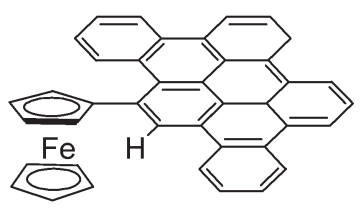

(II)
Fig. 1 The structures of the two known PAHs incorporating a ferrocene moiety 1,2-ferrocenyl-pyrenyl-ethene (I) and tetra-peri-benzo-periferrocenyl-coronene (II).

ethynylated cyclobutadienes, ${ }^{4-6} \eta^{6}$-tricarbonyl chromium ${ }^{7}$ and $\eta^{6}-[\mathrm{Rh}(\mathrm{COD})]^{+}$hexa-peri-hexabenzocoronene $(\mathrm{HBC})^{8}$ and HBCs incorporating $\sigma$-bonded Pt(II) acetylides. ${ }^{9}$

To date there are just two compounds reported where ferrocene is attached to an all-benzenoid PAH, one of which comprises four fused benzene rings, ${ }^{3}$ the other eight (Fig. 1). ${ }^{10}$ Both come some way short of the thirteen fused benzene rings found in HBC (Fig. 2). The L-shaped 1,2-ferrocenyl-pyrenyl-ethene (I) has fascinating solid state electrical conductivity properties ${ }^{3}$ whereas (II) with a single bond between the ferrocene moiety and the PAH fragment offers limited communication between the two end groups (Fig. 1). ${ }^{10}$

To combine the desirable features of both I and II we decided to increase the size of the PAH platform and to introduce an acetylene linker as an active pathway for electronic communication. Known ferrocenyl-acetylenes have been shown to have considerable potential in NLO, catalysis, as models of charge transfer and in the synthesis of more complex molecules with well-defined magnetic and electronic properties., ${ }^{41-13}$ Given these considerations, $\mathbf{1 3}$ became a desirable target molecule (Fig. 2). 


\section{Results and discussion}

The ferrocene moiety was incorporated into the polyphenylene systems by synthesising a library of novel ferrocene-containing precursors, suitable for subsequent [2+4] Diels-Alder cycloaddition and conversion to aromatic PAHs via cyclodehydrogenation. The synthesised molecules contained up to four

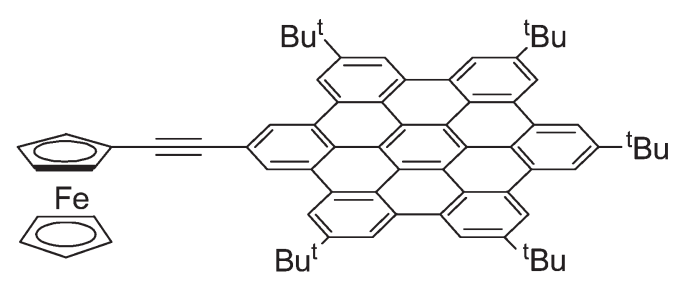

Fig. 2 Structure of 2-ethynylferrocenyl-5,8,11,14,17-penta-tert-butylhexa-peri-hexabenzocoronene (13). ferrocene units and in some cases nitrogen heteroatoms to aid solubility, and/or electron-rich methoxy groups. ${ }^{14,15}$ It was hoped that such derivatisation would yield highly conjugated systems with moderately electron-donating and electronaccepting regions.

\section{Synthesis of heteroatom-containing polyphenylenes 10, 11 and 12}

In order to incorporate multiple ferrocene moieties into the polyphenylene systems, di-ferrocenyl mono-ketone (4) was synthesised (Scheme 1). The initial step involved the synthesis of $\mathbf{1}$ via the diazotization reaction between ferrocene $(\mathrm{FcH})$ and 4-aminobenzylalcohol. The bromination of the hydroxyl group was achieved using phosphorous tribromide in dichloromethane which yielded $\mathbf{2}$, in almost quantitative yield. The new compound di-ferrocenyl ketone $\mathbf{4}$ was prepared by a bi-phasic, iron

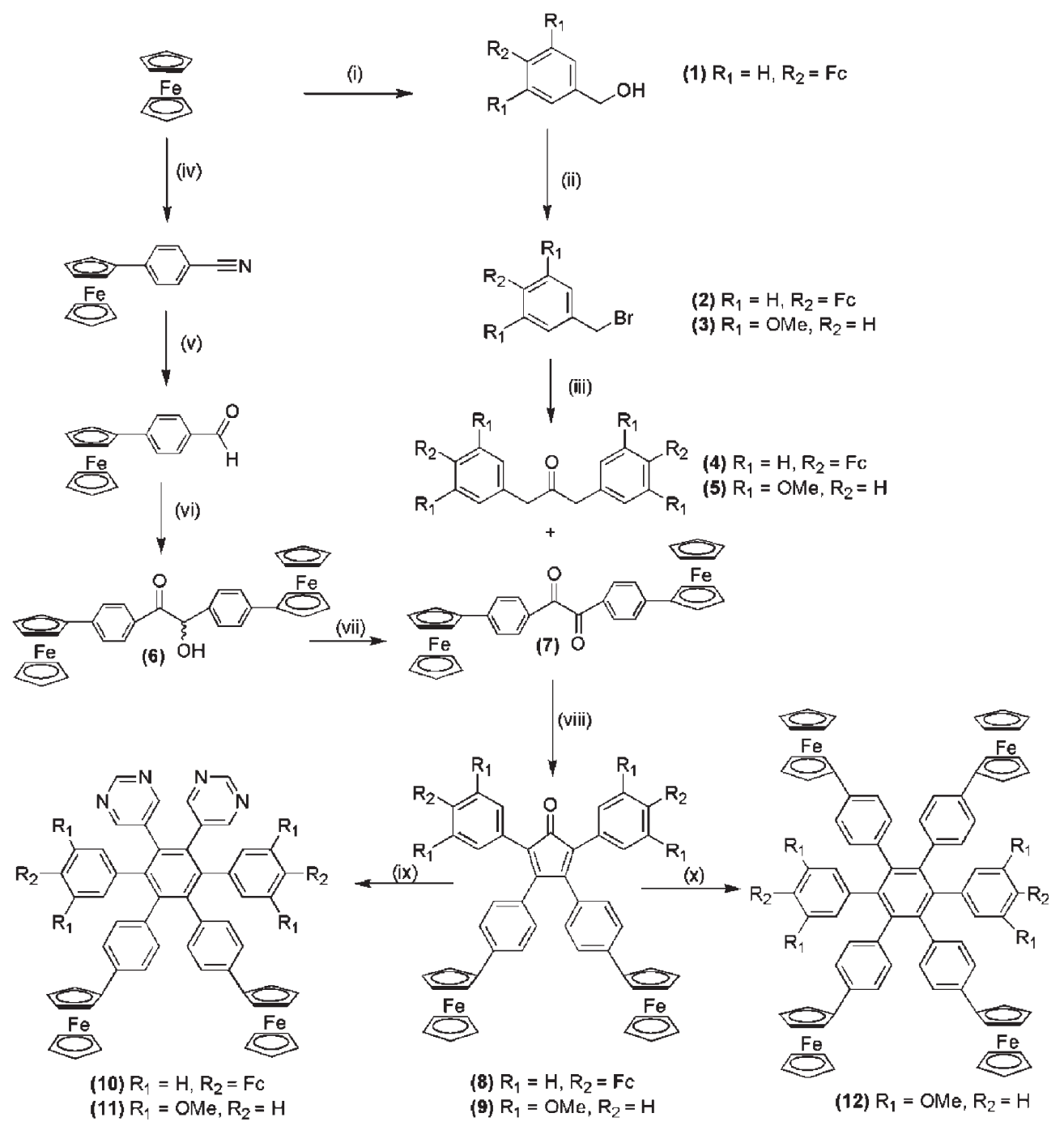

Scheme 1 The synthetic route to polyphenylenes 10, 11, and 12. (i) $\mathrm{H}_{2} \mathrm{SO}_{4} / \mathrm{H}_{2} \mathrm{O}$, sodium nitrite, 4-aminobenzylalcohol, $\mathrm{HCl}$, Cu powder, 24 h, 1 (31\%). (ii) $\mathrm{PBr}_{3}, \mathrm{CH}_{2} \mathrm{Cl}_{2}, 0{ }^{\circ} \mathrm{C}, 30$ min, 2 (94\%), (3 purchased directly). (iii) $\left.\mathrm{Ca}(\mathrm{OH})_{2}, \mathrm{Bu}_{4} \mathrm{~N}_{(\mathrm{HSO}}\right), \mathrm{Fe}(\mathrm{CO})_{5}, \mathrm{CH}_{2} \mathrm{Cl}{ }_{2} / \mathrm{H}_{2} \mathrm{O}, 6 \mathrm{~h}, 4(58 \%), 5(65 \%)$. (iv) $\mathrm{H}_{2} \mathrm{SO}_{4} / \mathrm{H}_{2} \mathrm{O}$, sodium nitrite, 4-aminobenzonitrile, $\mathrm{HCl}, \mathrm{Cu}$ powder, $24 \mathrm{~h}$, (35\%). (v) DIBAL, toluene, RT, $6 \mathrm{~h},(91 \%)$. (vi) NaCN, water/ethanol, reflux 1 h, 6 (59\%). (vii) $\mathrm{MnO}_{2}, \mathrm{CHCl}_{3}$, reflux, 24 h, 7 (88\%). (viii) $\mathrm{KOH}, \mathrm{C}_{2} \mathrm{H}_{5} \mathrm{OH} / \mathrm{CH}_{2} \mathrm{Cl}_{2}, 18 \mathrm{~h}(8) / 3$ h (9), 8 (63\%), 9 (64\%). (ix) Dipyrimidylacetylene, benzophenone, $200{ }^{\circ} \mathrm{C}, 18 \mathrm{~h}, \mathbf{1 0}(54 \%), 11(58 \%)$. (x) 1,2-Bis ( $p$-ferrocenylphenyl)acetylene, benzophenone, $190{ }^{\circ} \mathrm{C}, 18 \mathrm{~h}, \mathbf{1 2}(18 \%)$. 


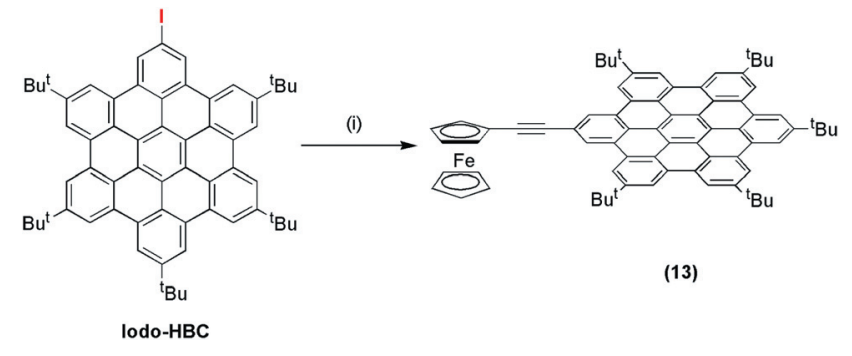

Scheme 2 Synthesis of $\mathbf{1 3}$ from iodo-HBC, (i) ethynyl ferrocene, $\mathrm{Pd}\left(\mathrm{PPh}_{3}\right)_{4}, \mathrm{Et}_{3} \mathrm{~N}$-toluene $(1: 2), 70{ }^{\circ} \mathrm{C}, 18 \mathrm{~h},(77 \%)$.

pentacarbonyl mediated coupling reaction. The methoxy-substituted 1,3-diaryl-2-propanone (5) was synthesised in a similar vein in $65 \%$ yield from the commercially available 3,-5dimethoxybenzyl bromide (3). As well as the di-ferrocenyl mono-ketone (4) the di-ferrocenyl di-ketone (7) was also prepared. This was achieved in four steps from ferrocene as illustrated in Scheme 1. The first step involved a diazotization reaction between ferrocene and 4-aminobenzonitrile ${ }^{16}$ to give 4-ferrocenylbenzonitrile (35\% yield), for conversion to 4 -ferrocenylbenzaldehyde in almost quantitative yield. The keto-alcohol 7 (also novel) was synthesised via the benzoin condensation of two molecules of 4-ferrocenylbenzaldehyde.

The two cyclopentadienones $\mathbf{8}$ and $\mathbf{9}$ were prepared via a twofold Knoevenagel condensation reaction between 7 and the corresponding mono-ketones (4 and 5). Both condensations were carried out in ethanolic potassium hydroxide solutions. Cyclopentadienone $\mathbf{8}$ was found to be quite unstable as a solid and particularly unstable in solution. Polyphenylenes $\mathbf{1 0}$ and $\mathbf{1 1}$ were obtained as orange crystalline solids via the Diels-Alder [2+4]cycloaddition of $\mathbf{8}$ and $\mathbf{9}$, respectively, with dipyrimidyl acetylene.

To expand the library of possible compounds, 1,2-bis ( $p$-ferrocenylphenyl)acetylene was successfully synthesised (Scheme S1, ESI + ) using a route that differs from that published by Rathore et $a l .{ }^{17}$ and subsequently used in a $[2+4]$ Diels-Alder cycloaddition with 9 to give tetra-ferrocenyl polyphenylene $\mathbf{1 2}$.

\section{Attempted cyclodehydrogenation of polyphenylenes 10, 11 and 12}

Attempts to cyclodehydrogenate ferrocenyl polyphenylenes $\mathbf{1 0}$ and $\mathbf{1 1}$ to form planar, ring-closed systems were unsuccessful, yielding only black, insoluble and un-characterisable solids indicative of complete decomposition. In an attempt to improve on these results, polyphenylene $\mathbf{1 2}$ was produced (Scheme 1) to incorporate electron-donating methoxy groups which are known to activate $\mathrm{C}-\mathrm{C}$ bond formation in cyclodehydrogenation reactions. This did not improve the outcome of the attempted cyclodehydrogenation which we believe to be a consequence of the partial oxidative decomposition by $\mathrm{Cu}(\mathrm{II})$ of the exposed $\mathrm{Fe}$ centre in tilted ferrocenyl moieties. ${ }^{6,10}$

\section{Synthesis and spectroscopic characterisation of 2-ethynylferrocenyl-5,8,11,14,17-penta-tert-butylhexa- peri-hexabenzocoronene (13)}

As a consequence of the unsuccessful cyclodehydrogenation of the ferrocene-containing 10, 11 and $\mathbf{1 2}$, a change of synthetic

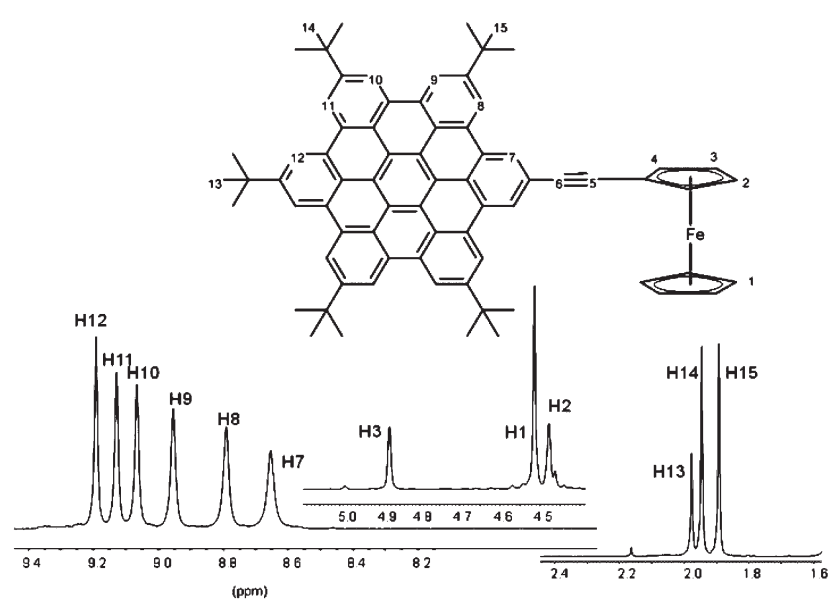

Fig. $3 \quad{ }^{1} \mathrm{H}$ NMR spectrum of $\mathbf{1 3}\left(\mathrm{CDCl}_{3}\right.$, RT, $\left.600 \mathrm{MHz}\right)$.

direction was required. Müllen et al. ${ }^{18,19}$ amongst others ${ }^{9,20}$ have shown that halogen atoms incorporated into PAH are labile enough to undergo palladium catalysed coupling reactions. It was decided to use iodo- $\mathrm{HBC}^{9,20}$ which would benefit from the efficient nature of the Scholl reaction for the $\mathrm{C}-\mathrm{C}$ bond formation in all-carbon polyphenylenes and simultaneously provide a predetermined site for the ferrocene moiety. Ethynyl ferrocene was synthesised according to literature procedures, ${ }^{38}$ and was cross-coupled with iodo-HBC using Sonogashira methodology to give $\mathbf{1 3}$ (Scheme 2).

The ${ }^{1} \mathrm{H}$ NMR spectrum of $\mathbf{1 3}$ consists of six well-defined singlets in the aromatic region due to the presence of a $C_{2}$ axis of symmetry which renders half the protons magnetically equivalent (Fig. 3). The ferrocenyl region exhibits the expected three signals corresponding to the two non-equivalent proton environments of the substituted cyclopentadienyl ring and the one proton environment of the protons on the unsubstituted cyclopentadienyl ring. In the aliphatic region three distinct signals are visible, integrating in the expected $1: 2: 2$ ratio for the tert-butyl groups.

The ${ }^{1} \mathrm{H}$ NMR spectrum of $\mathbf{1 3}$ was readily assigned by various NOE and 2D experiments using the clearly discernible signal for the tert-butyl group H13. TOCSY experiments provided evidence for the long range interactions between protons on adjacent rings and allowed a full assignment of the spectrum.

Phenyl groups prefer to associate in either an edge-to-edge or face-to-face orientation $\left(\pi-\pi\right.$ stacking) ${ }^{21}$ Such interactions have been the subject of a number of investigations ${ }^{21-23}$ that have attempted to address the role of molecular geometry ${ }^{22,23}$ and electrostatic factors in promoting aromatic association. ${ }^{24-27}$ The ${ }^{1} \mathrm{H}$ NMR signals of the aromatic protons of $\mathbf{1 3}$ were found to be concentration dependent, especially the upfield protons $\mathrm{H} 7, \mathrm{H} 8$ and H9, which are closest to the ferrocene moiety (Fig. 4). At ambient temperature in $\mathrm{CDCl}_{3}$ the chemical shift for $\mathrm{H} 7$ varied greatly from $\delta 8.90 \mathrm{ppm}\left(7.40 \times 10^{-3} \mathrm{M}\right)$ to $\delta 9.19 \mathrm{ppm}(0.06 \times$ $\left.10^{-3} \mathrm{M}\right)$ suggesting a significant degree of molecular aggregation. It has been shown by Moore et $a l^{28}$ that ethynyl moieties can form $\pi-\pi$ interactions with PAHs and macrocycles. The greatest overlap of $\pi$ orbitals in $\mathbf{1 3}$ is likely to be in the region closest to the electron donating ferrocene, hence the movement of $\mathrm{H} 7$ in the ${ }^{1} \mathrm{H}$ NMR spectrum. 


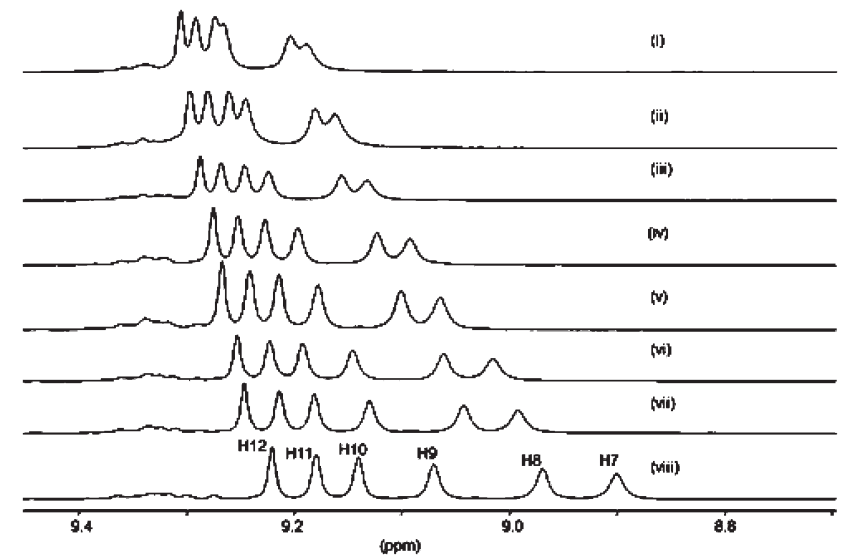

Fig. 4 The concentration dependence of the ${ }^{1} \mathrm{H}$ NMR aromatic signals of compound $13\left(\mathrm{CDCl}_{3}, \mathrm{RT}, 600 \mathrm{MHz}\right)$ : (i) $0.06 \mathrm{mmol} \mathrm{dm}^{-3}$, (ii) $0.12 \mathrm{mmol} \mathrm{dm}^{-3}$, (iii) $0.23 \mathrm{mmol} \mathrm{dm} \mathrm{dm}^{-3}$, (iv) $0.46 \mathrm{mmol} \mathrm{dm}^{-3}$, (v) $0.93 \mathrm{mmol} \mathrm{dm}^{-3}$, (vi) $1.85 \mathrm{mmol} \mathrm{dm}^{-3}$, (vii) $3.70 \mathrm{mmol} \mathrm{dm}^{-3}$, (viii) $7.40 \mathrm{mmol} \mathrm{dm}^{-3}$.

\section{UV-Vis absorption spectroscopy of polyphenylenes 10-12 and Fc-ethynyl-HBC (13)}

Electronic absorption spectra of ferrocene and substituted ferrocenes reveal that in ferrocene the metal centred $\mathrm{d}_{z}{ }^{2}$ orbital is generally the HOMO, a combination of the $\mathrm{d}_{x z}$ and $\mathrm{d}_{y z}$ is the LUMO and the LUMO +1 has a proposed composition of the $\mathrm{d}_{x y}$ and $\mathrm{d}_{x}{ }^{2}-{ }^{2} \cdot{ }^{29,30}$ The absorption around $\lambda 440 \mathrm{~nm}$ in ferrocene is thus assigned to the ${ }^{1} \mathrm{E}_{1 \mathrm{~g}} \leftarrow{ }^{1} \mathrm{~A}_{1 \mathrm{~g}}$ [LUMO $\leftarrow \mathrm{HOMO}$ ] ligand field (LF) transition and the higher energy band around $\lambda 325 \mathrm{~nm}$ to the ${ }^{1} \mathrm{E}_{2 \mathrm{~g}} \leftarrow{ }^{1} \mathrm{~A}_{1 \mathrm{~g}}$ [(LUMO +1$\left.) \leftarrow \mathrm{HOMO}\right] \mathrm{LF}$ transition. Substitution of a $\mathrm{Cp}$ ring in ferrocene with conjugated acceptor groups is generally followed by drastic changes in absorption spectra. ${ }^{29,30}$ LF, otherwise known as " $d-d$ " transitions, in organometallics are highly covalent and the electronic transitions involving d-orbitals are sensitive to ligand binding. ${ }^{31}$

This weak $d-d$ transition is evident between $\lambda 440-445 \mathrm{~nm}$ (Table 1) for each of the ferrocenyl-polyaromatic molecules prepared here (polyphenylenes 10-12 and Fc-HBC (13)) with weak extinction coefficients indicative of the forbidden nature of the transition $\left(\varepsilon=\right.$ molar extinction coefficient, $\left.\mathrm{L} \mathrm{mol}^{-1} \mathrm{~cm}^{-1}\right)$. The minor variation in the energy of this band reveals the weak influence that the nature of the substituent has on the transition.

For PAHs the dominant $\pi-\pi^{*}$ transitions usually occur in the $\lambda$ $300-420 \mathrm{~nm}$ region and are highly structured and well-resolved because of the delocalised and rigid nature of the molecular platform. The all-carbon HBC, hexa-tert-butyl-hexa-peri-hexabenzocoronene (14) was synthesised ${ }^{7}$ for direct comparison with $\mathbf{1 3}$ (Fig. 5).

The UV-Vis spectra of $\mathbf{1 3}$ and $\mathbf{1 4}$ have similar profiles; however as expected the absorptions in $\mathbf{1 3}$ are slightly redshifted. Both spectra show the three-band profile ( $\alpha, \beta$ and $p$ ), typical of aromatic hydrocarbons. The $\beta$-band appears at $\lambda$ $366 \mathrm{~nm}$ and corresponds to the electronic interaction between the benzenoid rings of the PAH. The p-bands appear at $\lambda 396 \mathrm{~nm}$ for $13(5 \mathrm{~nm}$ red shift compared to 14) and involve the localisation of the $\pi$-electrons in the excited state. The red-shifted band in $\mathbf{1 3}$ at $\lambda 414 \mathrm{~nm}$ is assigned to the $0-0,{ }^{1}\left(\pi, \pi^{*}\right)$ transition, with
Table 1 The UV-Vis data for ferrocene $(\mathrm{FcH})$ and compounds 10-13 in toluene $\left(\sim 10^{-5} \mathrm{M}\right)$

\begin{tabular}{lll}
\hline Compound & $\lambda_{\max } / \mathrm{nm},\left(\varepsilon / \mathrm{L} \mathrm{mol}^{-1} \mathrm{~cm}^{-1} \times 10^{3}\right)$ & $\begin{array}{l}\text { Low energy d-d } \\
\text { transition }\end{array}$ \\
\hline $\mathrm{FcH}$ & $325(0.5)$ & $439(0.5)$ \\
$\mathbf{1 0}$ & $355(12.6)$ & $443 / 5(2.8)$ \\
$\mathbf{1 1}$ & $354(12.1)$ & $440(2.6)$ \\
$\mathbf{1 2}$ & 350 sh $(1.7)$ & $445(0.3)$ \\
$\mathbf{1 3}$ & $334(27.3), 350(61.7), 366(138.7)$, & $c a .440$ \\
& $396(50.7), 414(19.0)$ & \\
\hline
\end{tabular}

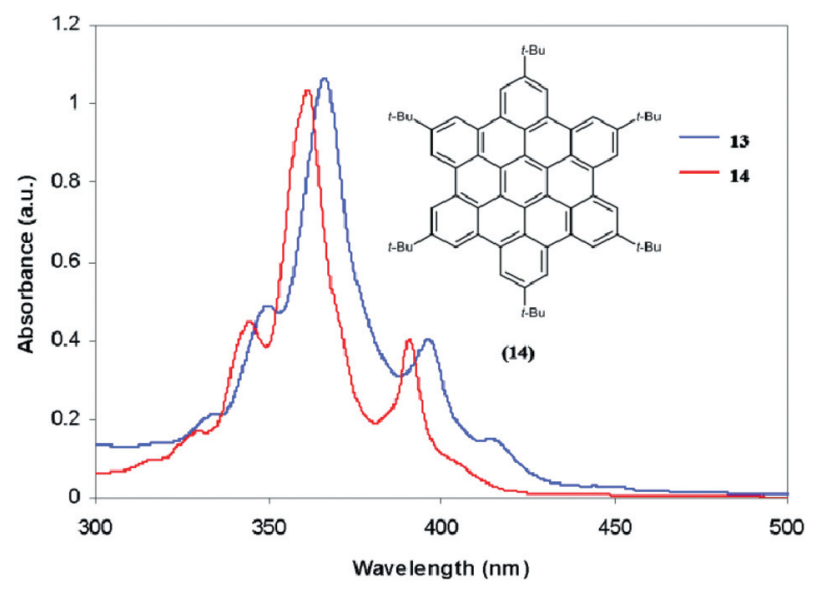

Fig. 5 The UV-Vis absorption spectra of $\mathbf{1 3}$ and $\mathbf{1 4}$ (inset) recorded in toluene $\left(10^{-5} \mathrm{M}\right)$.

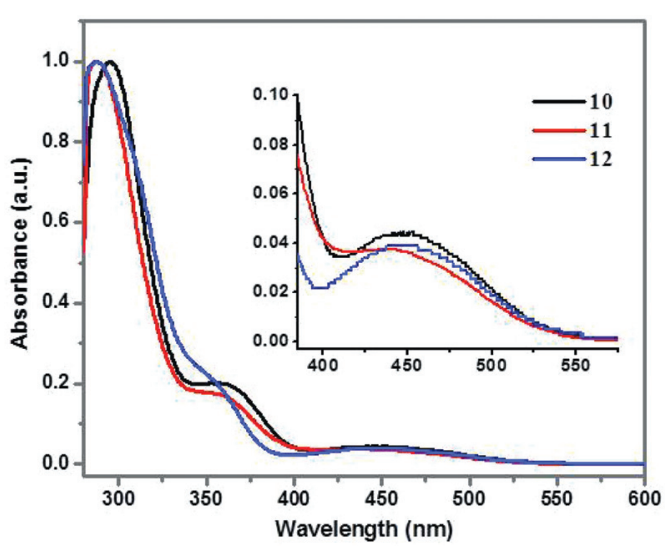

Fig. 6 Normalised UV-Vis absorption spectra of ferrocenyl-polyphenylenes 10-12 recorded in toluene $\left(\sim 10^{-5} \mathrm{M}\right)$ with inset lower energy region.

enhanced molar absorptivity compared to $\mathbf{1 4}$ due to the lifting of molecular symmetry $\left(D_{6 \mathrm{~h}}\right.$ to $\left.C_{2 \mathrm{v}}\right)$. The red-shift of these bands is indicative of an extension to the $\pi$-system of the HBC core, facilitated by the ethynyl linkage.

In contrast, the absorption spectra of polyphenylenes 10-12 are dominated by strong, high-energy absorption bands between $\lambda$ 300-350 $\mathrm{nm}$ attributable to $\pi \pi^{*}$ and $\mathrm{n} \pi^{*}$ transitions centred on the hexa-arylbenzene core (Fig. 6). Most probably the absence of effective conjugation between the ferrocenyl moiety and the polyphenylene occurs due to steric hindrance in the ground state. 
Table 2 Electrochemical data for ferrocenyl complexes ${ }^{a}$

\begin{tabular}{lll}
\hline Complex & $E^{\circ} / \mathrm{V}$ & $\Delta E_{\mathrm{p}} / \mathrm{mV}$ \\
\hline $\mathbf{1 0}$ & +0.03 & 169 \\
$\mathbf{1 1}$ & -0.01 & 120 \\
$\mathbf{1 2}$ & -0.06 & 114 \\
$\mathbf{1 3}$ & +0.14 & 136 \\
(II) & +0.04 & 70
\end{tabular}

${ }^{a}$ Redox potentials are given in $\mathrm{CH}_{2} \mathrm{Cl}_{2}$ solution $(1 \mathrm{mM})$, using a platinum disc working electrode, $\mathrm{Pt}$ wire auxiliary electrode, $\mathrm{Ag} / \mathrm{Ag}^{+}$ reference electrode, $100 \mathrm{mV} \mathrm{s}^{-1}$ scan rate with $0.1 \mathrm{M} \mathrm{Bu}_{4} \mathrm{NPF}_{6}$ as supporting electrolyte $\left(\mathrm{V} v s . \mathrm{Fc} / \mathrm{Fc}^{+}\right) . \Delta E_{\mathrm{p}}$ is given by $\left(E_{\mathrm{pa}}-E_{\mathrm{pc}}\right)$.

This would impose a non-planar configuration of the bound $\mathrm{Cp}$ and the phenyl ring of the hexa-arylbenzene and consequently inefficient orbital overlap.

\section{Electrochemistry}

The ferrocene/ferrocenium redox couple represents a strictly reversible one-electron process, although in some cases reversibility is lowered by the subsequent decomposition of the electrogenerated ferrocenium species. ${ }^{11}$ It gives information on any changes in the distribution of electron density and HOMO energies in a series of related compounds. ${ }^{11}$ The relevant electrochemical data for polyphenylenes 10-12 and Fc-HBC (13) and for tetra-peri-benzo-peri-ferrocenyl-coronene (II) (structure presented in Fig. 1) as $1 \mathrm{mM}$ dichloromethane solutions are compared in Table 2.

These compounds are electrochemically active and in each case, cyclic voltammetry in solution shows a single oxidation peak corresponding to the $\mathrm{Fe}(\mathrm{II}) / \mathrm{Fe}$ (III) redox couple. The oxidation potentials for 10-12 occur within the range -0.06 to $+0.03 \mathrm{~V}$, quite similar to ferrocene itself. This indicates that the electron density at the metal centre in these compounds, i.e. the energy of the HOMO, does not vary significantly upon changing substituents on the polyphenylene core. This is a consequence of the limited communication through the single carbon-carbon bond between the Fc moieties and the polyaromatic framework. Compounds $\mathbf{1 3}$ and (II) are usefully compared as both consist of a ferrocenyl moiety connected via a $\pi$-conjugated bridge to a fused aromatic platform. For (II) the fully reversible redox process was found to occur at $+0.04 \mathrm{~V}$ (vs. $\left.\mathrm{Fc} / \mathrm{Fc}^{+}\right)$. This is anodically shifted compared to the quasi-reversible oxidation of 13 and is indicative of a comparative reduction in electron density at the iron centre in $\mathbf{1 3}$ relative to (II), with the result that its metal centre is comparatively more difficult to oxidise. The acetylene-HBC unit has a considerable influence on the redox properties of the Fe core which we explored using theoretical methods.

\section{Theoretical considerations}

To support the experimental findings and to verify the electron distribution within Fc-ethynyl-HBC (13), calculations were performed (Gaussian 09, ${ }^{32}$ using the MO6 Hybrid functional ${ }^{33}$ and 6-31G(d,p) basis set) on the component fragments (Fe, $\mathrm{Cp}$, ethyne, and hexabenzocorenene (HBC)) in ferrocene, ethynyl-

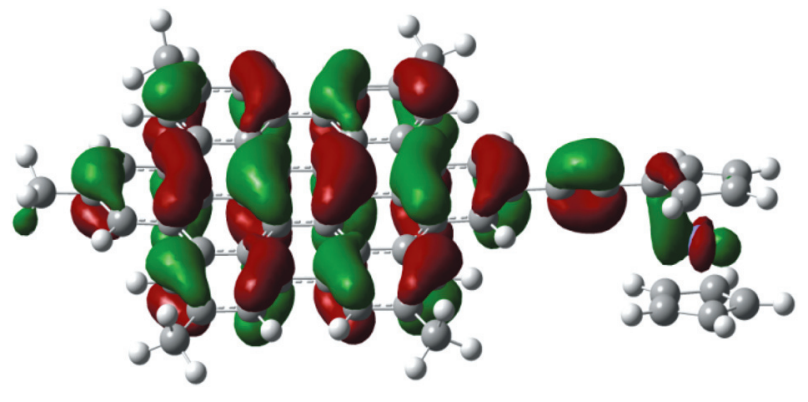

Fig. 7 HOMO of the methyl derivative of $\mathbf{1 3}$, calculated at the MO6/ 6-31G(d,p) level.

ferrocene, and the methyl derivative of $\mathbf{1 3}$ (methyl 13). Consistent with its highly conjugated $\pi$-system HBC was found to have the highest HOMO and lowest LUMO of the fragments considered. Ferrocene had the next highest HOMO and the next lowest LUMO (with a significant part of the wavefunction on the $\mathrm{Fe}$ ) and ethyne had the lowest HOMO and the highest LUMO. The energy of these frontier orbitals carried through to the HOMO of methyl 13 which was found to be composed primarily of the HBC HOMO containing significant contributions from both the ethyne (the lowest HOMO as an isolated molecule) and the Fe (Fig. 7).

While the HOMO provides information regarding the nature of the highest energy orbital, it does not provide information regarding the total charge redistribution. To assess this we performed Mullikan analysis (Table S1 $\dagger$ ) which shows that on going from ferrocene to ethynyl-ferrocene, the movement of charge occurs from the Fe and the ethynyl group to the attached cyclopentadienyl ring (Cp). (This is contrary to the commonly held view of ethynyl as electron withdrawing.) The addition of HBC increases the negative charge on the substituted cyclopentadiene and indeed on the acetylene linker itself which becomes integrated into an ethyne-HBC conjugated platform. The net effect is to depopulate the Fe further (and marginally depopulate the HBC).

The theoretical calculations show that the HOMO and LUMO states are not spatially different, indicating no charge transfer will occur upon excitation (assuming a primarily HOMOLUMO transition). This is consistent with the experimental findings: i.e. no charge transfer in the ground state absorption spectra and an increase in the oxidation potential on going from ferrocene to $\mathbf{1 3}$.

\section{NLO properties of 13}

A number of organic compounds have been studied as possible NLO materials as they offer some advantages over inorganic crystals. In general, organic NLO compounds comprise a bridged $\pi$-conjugation system and donor and acceptor end groups such as the fullerene-ferrocene dyads of Yamamoto et al. $^{34}$ (Scheme 3). One of these (III) is structurally related to 13, and therefore $\mathbf{1 3}$ offered an interesting comparator to these results.

The nonlinear response of $\mathbf{1 3}$ was studied by hyper Rayleigh scattering $(\mathrm{HRS})^{35-37}$ at $\lambda=1.9 \mu \mathrm{m}$ for comparison with those 


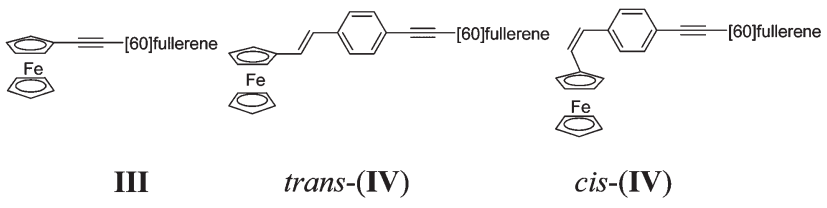

Scheme 3 Three fullerene-ferrocene dyads synthesised by Yamamoto et al. $^{34}$

Table 3 NLO response for compound 13, III, trans-(IV) and cis-(IV)

\begin{tabular}{lll}
\hline Complex & $\lambda_{0} / v \mu$ & $\beta^{a} / 10^{-30}$ esu \\
\hline $\mathbf{1 3}$ & 396 & $260^{a}$ \\
(III) & 328 & $173^{b}$ \\
trans-(IV) & 329 & $568^{b}$ \\
cis-(IV) & 324 & $374^{b}$
\end{tabular}

${ }^{a}$ Measured in chloroform by the HRS method at $1.910 \mu \mathrm{m} .{ }^{b}$ Measured in chloroform by the HRS method at $1.064 \mu \mathrm{m}$.

of (III), trans-(IV) and cis-(IV). As the UV-visible spectrum of 13 is complex, displaying several absorption bands, it was not appropriate to use a two-level dispersion model to infer a $\beta(0)$ that would be independent of the fundamental wavelength $\lambda$. From the data presented in Table 3 it is apparent that the $\beta$ value for $13\left(260 \times 10^{-30}\right.$ esu at $\left.\lambda=1.91 \mu \mathrm{m}\right)$ at a low resonance regime is higher than that of (III) $\left(173 \times 10^{-30}\right.$ esu at $\lambda=$ $1.06 \mu \mathrm{m})$ at a much more resonant regime. The direction and magnitude of this difference (a factor of 1.5 ) is particularly significant as all reported data on molecular NLO demonstrate an increase in $\beta$ when the fundamental wavelength comes close to the absorption maxima (i.e. in a more resonant regime) even in rather complex spectra. The improvement in the $\beta$ value also exceeds by far the experimental error of HRS measurements $(10 \%$ in our case) and thus the increase in hyperpolarizability can be attributed to the greater electron-accepting character of the ethynyl-HBC relative to ethynyl-fullerene. Molecules with yet higher conjugation lengths such as that present in trans-(IV) serve to maximise the NLO response further and to suggest structural features that would constitute desirable additions to future synthetic targets.

\section{Conclusions}

A number of synthetically useful ferrocenyl substituted diketones, monoketones and acetylenes have been prepared as building blocks in the formation of polyphenylenes that comprise up to four ferrocenyl units. Oxidative cyclodehydrogenation via $\mathrm{FeCl}_{3}$-catalysed oxidation was not successful; however hexa-peri-hexabenzocoronene (HBC) ethynyl ferrocene (13), a molecular form of organometallic graphene was prepared via Sonogashira coupling using iodo-HBC. The UV-visible absorption spectra, electrochemical and NLO data of this compound, confirm electron donation from the Fe to the highly delocalised Cp-ethynyl HBC unit. 13 is a novel conjugated organometallic graphene which warrants further solid-state investigation and synthetic derivatisation.

\section{Experimental}

Tetracyclone (Aldrich), ferrocene (Aldrich) and 3,-5-dimethoxybenzyl bromide 3 (Aldrich) were used as received. Ethynylferrocene $^{38}$ and dipyrimidyl acetylene ${ }^{39}$ and the uncyclised iodo-polyphenylene precursor ${ }^{20}$ were synthesised according to literature procedures. Flash chromatography was performed using silica gel (Brockman I, Aldrich Chemical) as the stationary phase. Preparative thin layer chromatography was performed using silica gel $(1000 \mu \mathrm{m}$ thickness) preparative thin layer chromatographic plates (Aldrich). NMR spectra were recorded in $\mathrm{CDCl}_{3}$ using a Bruker Avance DPX-400 MHz spectrometer (operating at $400.1 \mathrm{MHz}$ for ${ }^{1} \mathrm{H}, 100.6 \mathrm{MHz}$ for ${ }^{13} \mathrm{C}$ ) or where stated using a Bruker AV-600 MHz spectrometer $\left(600.1 \mathrm{MHz}\right.$ for ${ }^{1} \mathrm{H}$, $150.6 \mathrm{MHz}$ for $\left.{ }^{13} \mathrm{C}\right) .{ }^{1} \mathrm{H}$ and ${ }^{13} \mathrm{C}$ NMR spectra were referenced relative to TMS $(\delta 0.00 \mathrm{ppm})$. Chemical shifts $(\delta)$ are reported in ppm and coupling constants in Hertz. IR spectra (reported in $\mathrm{cm}^{-1}$ ) were made as neat samples and were recorded on a PerkinElmer Spectrum-One FT-IR spectrometer equipped with a Universal-ATR sampling accessory. Elemental analyses were performed in the Microanalytical Laboratory, University College Dublin. As is common for systems incorporating thermally robust polyaromatic frameworks, meaningful consistent elemental analysis results were difficult to obtain for compound $\mathbf{1 3}$ due to incomplete combustion of the fused all-carbon core. In the alternative, a ${ }^{1} \mathrm{H}$ NMR spectrum (Fig. 3) and the experimental (+)-MALDI-TOF spectra and $(\mathrm{MH})^{+}$simulated isotopic distribution pattern for this compound (Supporting Information, $\uparrow$ Fig. S1) are provided. Electrospray mass spectra were recorded on a Micromass-LCT spectrometer and accurate mass spectra were referenced against leucine enkephalin $\left([\mathrm{M}+\mathrm{H}]^{+} \mathrm{m} / \mathrm{z} 556.2771 \mathrm{~g} \mathrm{~mol}^{-1}\right)$ and reported to within $5 \mathrm{ppm}$. MALDI-TOF mass spectra were recorded on a Waters MALDI-QTOF premier spectrometer using an $\alpha$-cyano4-hydroxy cinnamic acid matrix and accurate mass spectra were referenced against $\left[\mathrm{Glu}^{1}\right]$-fibrinopeptide $\mathrm{B}\left([\mathrm{M}+\mathrm{H}]^{+} \mathrm{m} / \mathrm{z}\right.$ $1570.6768 \mathrm{~g} \mathrm{~mol}^{-1}$ ) and reported to within $5 \mathrm{ppm}$. Cyclic voltammetry was performed using a $\mathrm{CH}$ Instruments Electrochemical Analyser Model 600B. Cyclic voltammograms were measured on $1 \mathrm{mM}$ solutions using tetra- $n$-butylammonium hexafluorophosphate $\left(\mathrm{TBAPF}_{6}, 0.1 \mathrm{M}\right)$ as supporting electrolyte. A standard three electrode cell was employed with a glassy carbon working electrode, a Pt wire counter electrode and a SCE as the reference electrode. Potentials are quoted versus the ferrocene-ferrocenium couple $(0.0 \mathrm{~V})$ and all potentials were referenced to internal ferrocene added at the end of each experiment. Solutions were degassed for several minutes by nitrogen bubbling before and during the experiment. UV-Vis absorption spectra were recorded as optically dilute solutions $\left(10^{-4}-5 \times 10^{-7} \mathrm{M}\right)$ in $1 \times 1 \mathrm{~cm}^{2}$ quartz cuvettes on a Shimadzu UV-2450 spectrophotometer.

\section{Compound 1}

Ferrocene ( $7.6 \mathrm{~g}, 40.8 \mathrm{mmol})$ was added to sulfuric acid $(50 \mathrm{~mL}$, spec. grav. 1.84) and the resulting deep blue ferrocenium solution was stirred at room temperature for $2 \mathrm{~h}$. The solution was then poured into ice/water $(200 \mathrm{~mL})$ and allowed to warm to room temperature.

A solution of sodium nitrite $(1.82 \mathrm{~g}, 13.2 \mathrm{mmol})$ in water $(10 \mathrm{~mL})$ at $0{ }^{\circ} \mathrm{C}$ was added dropwise to a stirred solution of 
4-aminobenzylalcohol (3.0 g, $24 \mathrm{mmol})$ in $1: 1$ water/hydrochloric acid (spec. grav. 1.18) $(20 \mathrm{~mL})$ at $0{ }^{\circ} \mathrm{C}$, and stirred at this temperature for $30 \mathrm{~min}$ to ensure full diazotization. Copper powder $(2.0 \mathrm{~g})$ was added to the ferrocenium solution and the diazonium solution was added dropwise with vigorous stirring.

After $24 \mathrm{~h}$ stirring at room temperature, effervescence due to liberated nitrogen had ceased and ascorbic acid $(10 \mathrm{~g})$ was added to the dark mixture to reduce any remaining ferrocenium to ferrocene. Dichloromethane $(200 \mathrm{~mL})$ was added and the organic layer separated. The aqueous layer was extracted further with dichloromethane $(4 \times 100 \mathrm{~mL})$, and the combined organic extracts were filtered through celite before removal of the solvent in vacuo to give a dark brown solid. This was subjected to column chromatography using gradient elution. The first yellow fraction, eluted with hexane, yielded ferrocene. The second orange-red fraction was eluted with dichloromethane and 5\% methanol to give the desired product on removal of the solvents in vacuo as an orange solid $(2.2 \mathrm{~g}, 31 \%)$. mpt: $109-110{ }^{\circ} \mathrm{C}$. ${ }^{1} \mathrm{H}$ NMR $\left(\mathrm{CDCl}_{3}, 20{ }^{\circ} \mathrm{C}\right): \delta 7.50\left(\mathrm{~d}, 2 \mathrm{H},{ }^{3} J_{\mathrm{HH}}=8.3 \mathrm{~Hz},-\mathrm{CH}\right.$ Ar), $7.31\left(\mathrm{~d}, 2 \mathrm{H},{ }^{3} \mathrm{~J}_{\mathrm{HH}}=8.3 \mathrm{~Hz},-\mathrm{CH} \mathrm{Ar}\right), 4.69\left(\mathrm{~s}, 2 \mathrm{H},-\mathrm{CH}_{2}-\right)$, $4.67\left(\mathrm{t}, 2 \mathrm{H},{ }^{3} J_{\mathrm{HH}}=2.0 \mathrm{~Hz},-\mathrm{CH} \mathrm{Fc}\right), 4.34\left(\mathrm{t}, 2 \mathrm{H},{ }^{3} J_{\mathrm{HH}}=2.0 \mathrm{~Hz}\right.$, - CH Fc), 4.07 (s, 5H, -CH Fc), 1.73 (br s, $1 \mathrm{H},-\mathrm{OH}) .{ }^{13} \mathrm{C}\left\{{ }^{1} \mathrm{H}\right\}$ NMR $\left(\mathrm{CDCl}_{3}, 20{ }^{\circ} \mathrm{C}\right): \delta 138.34(1 \mathrm{C}$, quat $\mathrm{Ar}), 137.94(1 \mathrm{C}$, quat $\mathrm{Ar}), 126.78(2 \mathrm{C},-\mathrm{CH} \mathrm{Ar}), 125.82(2 \mathrm{C},-\mathrm{CH} \mathrm{Ar}), 84.60$ (1C, quat $\mathrm{Fc}), 69.17(5 \mathrm{C},-\mathrm{CH} \mathrm{Fc}), 68.52(2 \mathrm{C},-\mathrm{CH} \mathrm{Fc}), 66.06$ $(2 \mathrm{C},-\mathrm{CH} \mathrm{Fc}), 64.83\left(1 \mathrm{C},-\mathrm{CH}_{2}\right)$. ESI-MS (toluene) for $\mathrm{C}_{17} \mathrm{H}_{16} \mathrm{FeO}:[\mathrm{M}]^{+}$calculated $\mathrm{m} / \mathrm{z} 292.0551$, found $\mathrm{m} / z$ 292.0552. Anal. Calcd for $\mathrm{C}_{17} \mathrm{H}_{16} \mathrm{FeO} \cdot \mathrm{CH}_{2} \mathrm{Cl}_{2}: \mathrm{C}, 57.33 ; \mathrm{H}, 4.81$. Found: C, $57.41 ; \mathrm{H}, 4.87$.

\section{Compound 2}

Compound 1 (1 g, $3.42 \mathrm{mmol})$ was dissolved in dichloromethane $(20 \mathrm{~mL})$ in a 3-necked round bottomed flask. The mixture was cooled to $0{ }^{\circ} \mathrm{C}$, and a solution of phosphorous tribromide $(0.7 \mathrm{~mL}, 1.85 \mathrm{~g}, 6.85 \mathrm{mmol})$ dissolved in dichloromethane $(5 \mathrm{~mL})$ was added dropwise. The resulting mixture was then stirred at $0{ }^{\circ} \mathrm{C}$ for $30 \mathrm{~min}$. The reaction mixture was poured onto ice $(100 \mathrm{~g})$, neutralised with saturated aqueous sodium hydrogen carbonate solution and the organic phase separated. The aqueous phase was extracted with dichloromethane, and the organic phases were collected. These were washed with brine and dried over $\mathrm{MgSO}_{4}$ to yield the product as an orange powder on the removal of the solvent in vacuo (1.14 g, 94\%). mpt: $>200{ }^{\circ} \mathrm{C}$ (decomp.). ${ }^{1} \mathrm{H}$ NMR $\left(\mathrm{CDCl}_{3}, 20{ }^{\circ} \mathrm{C}\right): \delta 7.47$ (d, $2 \mathrm{H}$, $\left.{ }^{3} J_{\mathrm{HH}}=8.5 \mathrm{~Hz},-\mathrm{CH} \mathrm{Ar}\right), 7.33\left(\mathrm{~d}, 2 \mathrm{H},{ }^{3} J_{\mathrm{HH}}=8.5 \mathrm{~Hz},-\mathrm{CH} \mathrm{Ar}\right)$, $6.67\left(\mathrm{t}, 2 \mathrm{H},{ }^{3} \mathrm{~J}_{\mathrm{HH}}=2.0 \mathrm{~Hz},-\mathrm{CH} \mathrm{Fc}\right), 4.54\left(\mathrm{~s}, 2 \mathrm{H},-\mathrm{CH}_{2}-\right), 4.36$ $\left(\mathrm{s}, 2 \mathrm{H},{ }^{3} \mathrm{~J}_{\mathrm{HH}}=2.0 \mathrm{~Hz},-\mathrm{CH} \mathrm{Fc}\right), 4.08(\mathrm{~s}, 5 \mathrm{H},-\mathrm{CH} \mathrm{Fc}) .{ }^{13} \mathrm{C}\left\{{ }^{1} \mathrm{H}\right\}$ $\operatorname{NMR}\left(\mathrm{CDCl}_{3}, 20{ }^{\circ} \mathrm{C}\right) \delta: 139.46(1 \mathrm{C}$, quat $\mathrm{Ar}), 134.67(1 \mathrm{C}$, quat Ar), 128.69 (2C, $-\mathrm{CH} \mathrm{Ar}), 125.97(2 \mathrm{C},-\mathrm{CH} \mathrm{Ar}), 84.13$ (1C, quat $\mathrm{Fc}$ ), 69.23 (5C, $-\mathrm{CH} \mathrm{Fc}), 68.73(2 \mathrm{C},-\mathrm{CH} \mathrm{Fc}), 66.17$ (2C, $-\mathrm{CH} \mathrm{Fc}), 33.52\left(1 \mathrm{C},-\mathrm{CH}_{2}\right)$. Anal. Calcd for $\mathrm{C}_{17} \mathrm{H}_{15} \mathrm{BrFe}$ : $\mathrm{C}$, 57.51; H, 4.26. Found: C, 58.06; H, 4.42.

\section{Compound 4}

Calcium hydroxide $(2.3 \mathrm{~g}, 31 \mathrm{mmol})$ and tetrabutylammonium hydrogensulfate $(1.32 \mathrm{~g}, 3.88 \mathrm{mmol})$ were dissolved in $1: 1$ dichloromethane-water $(180 \mathrm{~mL})$. Argon was bubbled through the mixture for $30 \mathrm{~min}$ to degas the solution. Compound $\mathbf{2}$ $(5.5 \mathrm{~g}, 15.5 \mathrm{mmol})$ and iron pentacarbonyl $(1.1 \mathrm{~mL}, 7.75 \mathrm{mmol})$ were added to the reaction which was stirred at room temperature for six hours under a constant stream of argon. The reaction mixture was then oxidised in air and acidified with $10 \% \mathrm{HCl}$ $(120 \mathrm{~mL})$. The aqueous phase was extracted with dichloromethane and the organic washings were combined and their volume reduced under vacuum. Column chromatography on silica yielded the product as an orange solid after the removal of solvent in vacuo $(2.58 \mathrm{~g}, 58 \%)$. mpt: $>200{ }^{\circ} \mathrm{C}$ (decomp.). ${ }^{1} \mathrm{H}$ NMR $\left(\mathrm{CDCl}_{3}, 20{ }^{\circ} \mathrm{C}\right) \delta: 7.45\left(\mathrm{~d}, 4 \mathrm{H},{ }^{3} \mathrm{~J}_{\mathrm{HH}}=8.0 \mathrm{~Hz},-\mathrm{CH}\right.$ $\mathrm{Ar}), 7.11\left(\mathrm{~d}, 4 \mathrm{H},{ }^{3} \mathrm{~J}_{\mathrm{HH}}=8.0 \mathrm{~Hz},-\mathrm{CH} \mathrm{Ar}\right), 4.65\left(\mathrm{t}, 4 \mathrm{H},{ }^{3} \mathrm{~J}_{\mathrm{HH}}=\right.$ $2.0 \mathrm{~Hz},-\mathrm{CH} \mathrm{Fc}), 4.34\left(\mathrm{~s}, 4 \mathrm{H},{ }^{3} J_{\mathrm{HH}}=2.0 \mathrm{~Hz},-\mathrm{CH} \mathrm{Fc}\right), 4.07$ (s, $10 \mathrm{H},-\mathrm{CH} \mathrm{Fc}), 3.75$ (s, $\left.4 \mathrm{H},-\mathrm{CH}_{2}\right) \cdot{ }^{13} \mathrm{C}\left\{{ }^{1} \mathrm{H}\right\} \mathrm{NMR}\left(\mathrm{CDCl}_{3}\right.$, $\left.20{ }^{\circ} \mathrm{C}\right): \delta 205.47(1 \mathrm{C},-\mathrm{CO}), 137.66(2 \mathrm{C}$, quat $\mathrm{Ar}), 131.02(2 \mathrm{C}$, quat $\mathrm{Ar}), 129.07$ (4C, $-\mathrm{CH} \mathrm{Ar}), 125.98$ (4C, $-\mathrm{CH} \mathrm{Ar}), 84.60$ (2C, quat Fc), 69.18 (10C, $-\mathrm{CH} \mathrm{Fc}$ ), 68.49 (4C, $-\mathrm{CH} \mathrm{Fc}), 66.05$ $(4 \mathrm{C},-\mathrm{CH} \mathrm{Fc}), 48.41\left(2 \mathrm{C},-\mathrm{CH}_{2}\right)$. ESI-MS (toluene) for $\mathrm{C}_{35} \mathrm{H}_{30} \mathrm{Fe}_{2} \mathrm{ONa}:[\mathrm{M}+\mathrm{Na}]^{+}$calculated $\mathrm{m} / z$ 601.0893, found $\mathrm{m} / \mathrm{z}$ 601.0919. IR vbar $\left(\mathrm{cm}^{-1}\right): v(\mathrm{C}-\mathrm{H}$ st, aromatic): 3092, 3031, $v(\mathrm{C}=\mathrm{O}$ st $): 1722, v(\mathrm{C}=\mathrm{C}$ st $): 1612,1603,1527, v(\mathrm{C}-\mathrm{H}$ rock Fc): $1103,1083,1056,999$. Anal. Calcd for $\mathrm{C}_{35} \mathrm{H}_{30} \mathrm{Fe}_{2} \mathrm{O} \cdot \frac{1}{2} \mathrm{H}_{2} \mathrm{O}$ : C, 71.58; H, 5.32. Found: C, 71.82; H, 5.16.

\section{Compound 5}

Calcium hydroxide $(3.2 \mathrm{~g}, 43.2 \mathrm{mmol})$ and tetrabutylammonium hydrogensulfate $(1.83 \mathrm{~g}, 5.7 \mathrm{mmol})$ were dissolved in $1: 1$ dichloromethane-water $(240 \mathrm{~mL})$ and argon was bubbled through the reaction mixture for $30 \mathrm{~min}$ to degas the solution. 3,5-Dimethoxybenzyl bromide (3) $(5.0 \mathrm{~g}, 21.6 \mathrm{mmol})$ was added followed by iron pentacarbonyl $(1.5 \mathrm{~mL}, 10.8 \mathrm{mmol})$ and the reaction was stirred at room temperature for five and a half hours under a constant stream of argon. The reaction mixture was then oxidised in air and acidified with $10 \% \mathrm{HCl}(120 \mathrm{~mL})$. The aqueous phase was extracted with dichloromethane and the organic washings were combined and the volume reduced in vacuo to give a yellow/orange oil. The oil was subjected to column chromatography on silica. Eluting with diethyl ether yielded the desired product as an off-white waxy solid $(2.3 \mathrm{~g}$, $65 \%$ ). mpt: $78-80{ }^{\circ} \mathrm{C} .{ }^{1} \mathrm{H}$ NMR $\left(\mathrm{CDCl}_{3}, 20{ }^{\circ} \mathrm{C}\right): \delta 6.39$ (t, $2 \mathrm{H}$, $\left.{ }^{4} J_{\mathrm{HH}}=2.0 \mathrm{~Hz},-\mathrm{CH} \mathrm{Ar}\right), 6.32\left(\mathrm{~d}, 4 \mathrm{H},{ }^{4} J_{\mathrm{HH}}=2.0 \mathrm{~Hz},-\mathrm{CH} \mathrm{Ar}\right)$, $3.78\left(\mathrm{~s}, 12 \mathrm{H},-\mathrm{OCH}_{3}\right), 3.66\left(\mathrm{~s}, 4 \mathrm{H},-\mathrm{CH}_{2}-\right) \cdot{ }^{13} \mathrm{C}\left\{{ }^{1} \mathrm{H}\right\} \mathrm{NMR}$ $\left(\mathrm{CDCl}_{3}, 20{ }^{\circ} \mathrm{C}\right): \delta 205.04(1 \mathrm{C},-\mathrm{CO}), 160.51$ (4C, quat $\mathrm{Ar}$ ), 135.64 (2C, quat $\mathrm{Ar}), 107.07(4 \mathrm{C},-\mathrm{CH} \mathrm{Ar}), 98.71$ (2C, $-\mathrm{CH} \mathrm{Ar}), 54.86\left(2 \mathrm{C},-\mathrm{CH}_{2}-\right), 48.78\left(4 \mathrm{C},-\mathrm{OCH}_{3}\right)$. ESI-MS (methanol) for $\mathrm{C}_{19} \mathrm{H}_{22} \mathrm{O}_{5} \mathrm{Na}:[\mathrm{M}+\mathrm{Na}]^{+}$calculated $\mathrm{m} / \mathrm{z}$ 353.1365, found $m / z$ 353.1374. Anal. Calcd for $\mathrm{C}_{19} \mathrm{H}_{22} \mathrm{O}_{5}$ : C, 69.07; H, 6.71. Found: C, 69.34; H, 6.84.

\section{Compound 6}

4-Ferrocenylbenzoaldehyde ( $2 \mathrm{~g}, 6.89 \mathrm{mmol})$ and sodium cyanide $(0.6 \mathrm{~g}, 12.2 \mathrm{mmol})$ were dissolved in water $(3 \mathrm{~mL})$ and ethanol $(10 \mathrm{~mL})$ and refluxed for $1 \mathrm{~h}$. The solution was cooled, resulting in a red precipitate, which was collected by suction filtration. The precipitate was dried and subjected to column 
chromatography on silica eluting with dichloromethane. The first orange band yielded unreacted 4-ferrocenylbenzaldehyde and the second orange-red band afforded the desired product as an orange crystalline solid on recrystallisation from hexane $(1.18 \mathrm{~g}$, 59\%). mpt: $117-118{ }^{\circ} \mathrm{C}$. ${ }^{1} \mathrm{H}$ NMR $\left(\mathrm{CDCl}_{3}, 20{ }^{\circ} \mathrm{C}\right): \delta 7.87$ (d, $2 \mathrm{H},{ }^{3} J_{\mathrm{HH}}=8.5 \mathrm{~Hz},-\mathrm{CH}$ Ar), 7.47,(m, 4H, -CH Ar), 7.30 $\left(\mathrm{d}, 2 \mathrm{H},{ }^{3} J_{\mathrm{HH}}=8.5 \mathrm{~Hz},-\mathrm{CH} \mathrm{Ar}\right), 5.91\left(\mathrm{~d}, 1 \mathrm{H},{ }^{3} J_{\mathrm{HH}}=6.0 \mathrm{~Hz}\right.$, $-\mathrm{CH}(\mathrm{OH})), 4.68$ (s, 2H, - CH Fc), 4.63 (s, 2H, - CH Fc), 4.55 (d, $\left.1 \mathrm{H},{ }^{3} J_{\mathrm{HH}}=6.0 \mathrm{~Hz},-\mathrm{OH}\right), 4.41(\mathrm{~s}, 2 \mathrm{H},-\mathrm{CH} \mathrm{Fc}), 4.32(\mathrm{~s}, 2 \mathrm{H}$, $-\mathrm{CH} \mathrm{Fc}), 4.02(\mathrm{~s}, 10 \mathrm{H},-\mathrm{CH} \mathrm{Fc}) .{ }^{13} \mathrm{C}\left\{{ }^{1} \mathrm{H}\right\} \mathrm{NMR}\left(\mathrm{CDCl}_{3}\right.$, $\left.20{ }^{\circ} \mathrm{C}\right): \delta 197.63(1 \mathrm{C},-\mathrm{CO}), 146.39$ (1C, quat $\left.\mathrm{Ar}\right), 139.41(1 \mathrm{C}$, quat $\mathrm{Ar}), 136.52$ (1C, quat $\mathrm{Ar}), 130.19$ (1C, quat $\mathrm{Ar}), 128.84$ (2C, - CH Ar), 127.30 (2C, -CH Ar), 126.19 (2C, -CH Ar), 125.31 (2C, $-\mathrm{CH} \mathrm{Ar}), 83.95$ (1C, quat $\mathrm{Fc}$ ), 82.17 (1C, quat $\mathrm{Fc}$ ), $75.25(1 \mathrm{C},-\mathrm{CH}(\mathrm{OH})), 69.39(5 \mathrm{C},-\mathrm{CH} \mathrm{Fc}), 69.14(5 \mathrm{C},-\mathrm{CH}$ $\mathrm{Fc}), 66.66$ (2C, $-\mathrm{CH} \mathrm{Fc}), 66.46$ (2C, $-\mathrm{CH} \mathrm{Fc}), 66.09$ (2C, $-\mathrm{CH}$ Fc), 66.06 (2C, $-\mathrm{CH} \mathrm{Fc).} \mathrm{ESI-MS} \mathrm{(methanol)} \mathrm{for} \mathrm{C}_{34} \mathrm{H}_{28} \mathrm{Fe}_{2} \mathrm{O}_{2}$ : $[\mathrm{M}]^{+}$calculated $\mathrm{m} / \mathrm{z}$ 580.0788, found $\mathrm{m} / \mathrm{z}$ 580.0773. IR $v$ bar $\left(\mathrm{cm}^{-1}\right): v(\mathrm{O}-\mathrm{H} \mathrm{st}): 3444, v(\mathrm{C}-\mathrm{H} \mathrm{st}$, aromatic $): 3095,2960$, $v(\mathrm{C}=\mathrm{O}$ st $): 1665, v(\mathrm{C}=\mathrm{C} \mathrm{st}): 1601,1561,1526, v(\mathrm{C}-\mathrm{H}$ rock Fc): 1106, 1069, 1031. Anal. Calcd for $\mathrm{C}_{34} \mathrm{H}_{28} \mathrm{Fe}_{2} \mathrm{O}_{2}$ : C, 70.37; H, 4.86. Found: C, 70.42; H, 5.00.

\section{Compound 7}

(Reaction carried out in air.) Compound 6 (1.2 g, $2.07 \mathrm{mmol}$ ) was dissolved in chloroform $(30 \mathrm{~mL})$. Manganese dioxide $(0.72 \mathrm{~g}, 8.27 \mathrm{mmol})$ was added and the mixture was refluxed for $24 \mathrm{~h}$. After cooling to room temperature, the solution was filtered through celite and the filtrant was washed until the filtrate ran clear. The solvent was removed in vacuo yielding the desired product as an orange-red solid (1.05 g, 88\%). mpt: $134-135{ }^{\circ} \mathrm{C}$. ${ }^{1} \mathrm{H}$ NMR $\left(\mathrm{CDCl}_{3}, 20{ }^{\circ} \mathrm{C}\right): \delta 7.93\left(\mathrm{~d}, 4 \mathrm{H},{ }^{3} J_{\mathrm{HH}}=8.5 \mathrm{~Hz},-\mathrm{CH}\right.$ Ar), $7.57\left(\mathrm{~d}, 4 \mathrm{H},{ }^{3} J_{\mathrm{HH}}=8.5 \mathrm{~Hz},-\mathrm{CH} \mathrm{Ar}\right), 4.77\left(\mathrm{t}, 4 \mathrm{H},{ }^{3} J_{\mathrm{HH}}=\right.$ $1.5 \mathrm{~Hz},-\mathrm{CH} \mathrm{Fc}), 4.47\left(\mathrm{t}, 4 \mathrm{H},{ }^{3} J_{\mathrm{HH}}=1.5 \mathrm{~Hz},-\mathrm{CH} \mathrm{Fc}\right), 4.07(\mathrm{~s}$, $10 \mathrm{H},-\mathrm{CH} \mathrm{Fc}) .{ }^{13} \mathrm{C}\left\{{ }^{1} \mathrm{H}\right\} \mathrm{NMR}\left(\mathrm{CDCl}_{3}, 20{ }^{\circ} \mathrm{C}\right): \delta 193.71(2 \mathrm{C}$, -CO), 147.54 (2C, quat Ar), 129.95 (2C, quat Ar), 129.75 (4C, - $\mathrm{CH}$ Ar), 125.61 (4C, - CH Ar), 82.38 (2C, quat Fc), 70.14 (4C, -CH Fc), 69.78 (10C, -CH Fc), 66.89 (4C, -CH Fc). ESI-MS (methanol) for $\mathrm{C}_{34} \mathrm{H}_{26} \mathrm{Fe}_{2} \mathrm{O}_{2} \mathrm{Na}:[\mathrm{MNa}]^{+}$calculated $\mathrm{m} / \mathrm{z}$ 601.0529 , found $\mathrm{m} / \mathrm{z} 601.0532$. IR $v$ bar $\left(\mathrm{cm}^{-1}\right): v(\mathrm{C}-\mathrm{H}$ st, aromatic): 3096, 2961, $v(\mathrm{C}=\mathrm{O}, \mathrm{st}): 1670,1658, v(\mathrm{C}=\mathrm{C}$ st $): 1604$, 1560, 1523, $v(\mathrm{C}-\mathrm{H}$ rock $\mathrm{Fc}): 1218,1173,1103,1082$. Anal. Calcd for $\mathrm{C}_{34} \mathrm{H}_{26} \mathrm{Fe}_{2} \mathrm{O}_{2} \cdot \mathrm{H}_{2} \mathrm{O}: \mathrm{C}, 68.49 ; \mathrm{H}$, 4.73. Found: $\mathrm{C}$, 68.61; H, 4.73.

\section{Compound 8}

Diketone 7 (0.5 g, $0.86 \mathrm{mmol})$ and potassium hydroxide $(0.08 \mathrm{~g}$, $1.47 \mathrm{mmol})$ were dissolved in ethanol $(25 \mathrm{~mL})$ and heated to reflux. A solution of $4(0.55 \mathrm{~g}, 0.95 \mathrm{mmol})$ dissolved in ethanol-dichloromethane, $1: 1(45 \mathrm{~mL})$ and added dropwise to the mixture which was then refluxed for $18 \mathrm{~h}$. The solution was cooled to room temperature, and the resulting precipitate was filtered and washed with ethanol followed by hexane to yield the desired product as an unstable purple solid $(0.61 \mathrm{~g}$, $63 \%$ ). mpt: $<100{ }^{\circ} \mathrm{C}$ (decomp.). ${ }^{1} \mathrm{H} \mathrm{NMR} \mathrm{(600.1} \mathrm{MHz)}\left(\mathrm{CDCl}_{3}\right.$, $\left.20{ }^{\circ} \mathrm{C}\right): \delta 7.39\left(\mathrm{~d}, 4 \mathrm{H},{ }^{3} J_{\mathrm{HH}}=8.5 \mathrm{~Hz},-\mathrm{CH} \mathrm{Ar}\right), 7.34(\mathrm{~d}, 4 \mathrm{H}$, $\left.{ }^{3} J_{\mathrm{HH}}=8.0 \mathrm{~Hz},-\mathrm{CH} \mathrm{Ar}\right), 7.30\left(\mathrm{~d}, 4 \mathrm{H},{ }^{3} J_{\mathrm{HH}}=8.0 \mathrm{~Hz},-\mathrm{CH} \mathrm{Ar}\right)$, $6.94\left(\mathrm{~d}, 4 \mathrm{H},{ }^{3} J_{\mathrm{HH}}=8.5 \mathrm{~Hz},-\mathrm{CH} \mathrm{Ar}\right), 4.67\left(\mathrm{t}, 4 \mathrm{H},{ }^{3} J_{\mathrm{HH}}=\right.$ $2.0 \mathrm{~Hz},-\mathrm{CH} \mathrm{Fc}), 4.64\left(\mathrm{t}, 4 \mathrm{H},{ }^{3} J_{\mathrm{HH}}=2.0 \mathrm{~Hz},-\mathrm{CH} \mathrm{Fc}\right), 4.35(\mathrm{t}$, $\left.4 \mathrm{H},{ }^{3} J_{\mathrm{HH}}=2.0 \mathrm{~Hz},-\mathrm{CH} \mathrm{Fc}\right), 4.33\left(\mathrm{t}, 4 \mathrm{H},{ }^{3} J_{\mathrm{HH}}=2.0 \mathrm{~Hz}\right.$, $-\mathrm{CH} \mathrm{Fc}), 4.05$ (s, 10H, - CH Fc), 4.04 (s, 10H, - CH Fc). ${ }^{13} \mathrm{C}$ $\left\{{ }^{1} \mathrm{H}\right\} \mathrm{NMR}(150.6 \mathrm{MHz})\left(\mathrm{CDCl}_{3}, 20{ }^{\circ} \mathrm{C}\right): \delta 200.74(1 \mathrm{C},-\mathrm{CO})$, 153.79 (2C, quat $\mathrm{Ar}$ ), 139.94 (2C, quat $\mathrm{Ar}$ ), 138.38 (2C, quat $\mathrm{Ar}), 130.76$ (2C, quat Ar), 129.92 (4C, - $\mathrm{CH} \mathrm{Ar}), 129.51$ (4C, - $\mathrm{CH} \mathrm{Ar}$ ), 128.50 (2C, quat Ar), 125.53 (4C, - CH Ar), 124.95 (4C, $-\mathrm{CH} \mathrm{Ar}$ ), 124.49 (2C, quat $\mathrm{Ar}$ ), 84.78 (2C, quat Fc), 83.70 (2C, quat Fc), 69.75 (10C, - CH Fc), 69.51 (10C, - $\mathrm{CH} \mathrm{Fc),}$ 69.36 (4C, - CH Fc), 68.93 (4C, - CH Fc)), 66.32 (4C, - CH Fc), 66.25 (4C, - $\mathrm{CH}$ Fc). MALDI-TOF MS (methanol) for $\mathrm{C}_{69} \mathrm{H}_{52} \mathrm{Fe}_{4} \mathrm{O}: \quad[\mathrm{M}]^{+}$calculated $\mathrm{m} / \mathrm{z}$ 1120.1416, found $\mathrm{m} / \mathrm{z}$ 1120.1416. IR vbar $\left(\mathrm{cm}^{-1}\right): v(\mathrm{C}-\mathrm{H}$ st, aromatic $): 3076, v(\mathrm{C}=\mathrm{O}$ st): $1706, v(\mathrm{C}=\mathrm{C}$ st $): 1600,1526,1517, v(\mathrm{C}-\mathrm{H}$ rock $\mathrm{Fc}): 1103$, 1088, 1082, 1017. Note: Instability of solid precluded C, H, N analysis.

\section{Compound 9}

Diketone 7 (1.3 g, $2.25 \mathrm{mmol})$ and potassium hydroxide $(0.22 \mathrm{~g}$, $3.85 \mathrm{mmol})$ were dissolved in ethanol $(25 \mathrm{~mL})$ and heated to reflux. A solution of $5(0.79 \mathrm{~g}, 2.4 \mathrm{mmol})$ was dissolved in ethanol $(25 \mathrm{~mL})$ and added dropwise to the reaction mixture which was refluxed for $3 \mathrm{~h}$. The solution was then cooled slowly to room temperature and the dark green crystalline product was isolated by filtration $(0.38 \mathrm{~g}, 64 \%)$. mpt: $204-205{ }^{\circ} \mathrm{C} .{ }^{1} \mathrm{H}$ NMR $\left(\mathrm{CDCl}_{3}, 20{ }^{\circ} \mathrm{C}\right): \delta 7.32\left(\mathrm{~d}, 4 \mathrm{H},{ }^{3} J_{\mathrm{HH}}=8.5 \mathrm{~Hz},-\mathrm{CH} \mathrm{Ar}\right), 6.91$ $\left(\mathrm{d}, 4 \mathrm{H},{ }^{3} J_{\mathrm{HH}}=8.5 \mathrm{~Hz},-\mathrm{CH} \mathrm{Ar}\right), 6.51\left(\mathrm{~d}, 4 \mathrm{H},{ }^{4} J_{\mathrm{HH}}=2.0 \mathrm{~Hz}\right.$, -CH Ar), $6.39\left(\mathrm{t}, 2 \mathrm{H},{ }^{4} J_{\mathrm{HH}}=2.0 \mathrm{~Hz},-\mathrm{CH} \mathrm{Ar}\right), 4.64(\mathrm{t}, 4 \mathrm{H}$, $\left.{ }^{3} J_{\mathrm{HH}}=1.8 \mathrm{~Hz},-\mathrm{CH} \mathrm{Fc}\right), 4.34\left(\mathrm{t}, 4 \mathrm{H},{ }^{3} J_{\mathrm{HH}}=1.8 \mathrm{~Hz},-\mathrm{CH} \mathrm{Fc}\right)$, $4.01(\mathrm{~s}, 10 \mathrm{H},-\mathrm{CH} \mathrm{Fc}), 3.66\left(\mathrm{~s}, 12 \mathrm{H},-\mathrm{OCH}_{3}\right) .{ }^{13} \mathrm{C}\left\{{ }^{1} \mathrm{H}\right\} \mathrm{NMR}$ $\left(\mathrm{CDCl}_{3}, 20{ }^{\circ} \mathrm{C}\right) \delta$ : $199.36(1 \mathrm{C},-\mathrm{CO}), 159.81$ (4C, quat $\left.\mathrm{Ar}\right)$, 154.30 (2C, quat $\mathrm{Ar}$ ), 139.78 (2C, quat $\mathrm{Ar}), 132.17$ (2C, quat Ar), 129.98 (2C, quat Ar), 129.16 (4C, $-\mathrm{CH} \mathrm{Ar}), 124.68$ (4C, - $\mathrm{CH}$ Ar), 124.26 (2C, quat Ar), 107.47 (4C, $-\mathrm{CH}$ Ar), 100.11 (2C, $-\mathrm{CH} \mathrm{Ar}), 83.40$ (2C, quat Fc), 69.37 (10C, $-\mathrm{CH} \mathrm{Fc}), 69.04$ (4C, $-\mathrm{CH} \mathrm{Fc}), 65.96(4 \mathrm{C},-\mathrm{CH} \mathrm{Fc}), 54.71\left(4 \mathrm{C},-\mathrm{OCH}_{3}\right)$. ESI-MS (toluene) for $\mathrm{C}_{53} \mathrm{H}_{44} \mathrm{Fe}_{2} \mathrm{O}_{5}:[\mathrm{M}]^{+}$calculated $\mathrm{m} / \mathrm{z}$ 872.1888, found $m / z$ 872.1897. IR $v$ bar $\left(\mathrm{cm}^{-1}\right): v(\mathrm{C}-\mathrm{H}$ st, aromatic): 3086, 2997, $v\left(\mathrm{C}-\mathrm{H}\right.$ st, $\left.-\mathrm{OCH}_{3}\right): 2834, v(\mathrm{C}=\mathrm{O} \mathrm{st}): 1702$, $v(\mathrm{C}=\mathrm{C}$ st $): 1603,1589,1524, v\left(\mathrm{C}-\mathrm{O}\right.$ st,$\left.-\mathrm{OCH}_{3}\right): 1275, v(\mathrm{C}-\mathrm{H}$ rock Fc): 1193, 1104, 1096, 1044. Anal. Calcd for $\mathrm{C}_{53} \mathrm{H}_{44} \mathrm{Fe}_{2} \mathrm{O}_{5}$ : C, 72.95; H, 5.08. Found: C, 72.71; H, 4.89.

\section{Compound 10}

Cyclopentadienone 8 ( $0.25 \mathrm{~g}, 0.22 \mathrm{mmol})$, di(5-pyrimidyl)acetylene $(0.037 \mathrm{~g}, 0.2 \mathrm{mmol})$ and benzophenone $(1.0 \mathrm{~g})$ were mixed in a round bottomed flask and attached to an air condenser. The mixture was heated at $200{ }^{\circ} \mathrm{C}$ for $18 \mathrm{~h}$. The mixture was then subjected to flash column chromatography on silica. Eluting with dichloromethane removed all the benzophenone and any un-reacted cyclopentadienone. Elution with diethyl ether-methanol $(10: 1)$ and removal of the solvents yielded the desired product as a light orange powder $(0.14 \mathrm{~g}, 54 \%)$. mpt: $>200{ }^{\circ} \mathrm{C}$ (decomp.). ${ }^{1} \mathrm{H}$ NMR (600.1 MHz) $\left(\mathrm{CDCl}_{3}, 20{ }^{\circ} \mathrm{C}\right): \delta 8.81(\mathrm{~s}$, 
$2 \mathrm{H},-\mathrm{CH}$ Ar), 8.32 (s, 4H, $-\mathrm{CH}$ Ar), $7.12\left(\mathrm{~d}, 4 \mathrm{H},{ }^{3} J_{\mathrm{H} 1 \mathrm{H}}=8.0\right.$ $\mathrm{Hz},-\mathrm{CH} \mathrm{Ar}), 7.07$ (d, 4H, ${ }^{3} J_{\mathrm{HH}}=8.0 \mathrm{~Hz},-\mathrm{CH}$ Ar), 6.81 (d, 4H, ${ }^{3} J_{\mathrm{HH}}=8.0 \mathrm{~Hz},-\mathrm{CH}$ Ar), $6.78\left(\mathrm{~d}, 4 \mathrm{H},{ }^{3} J_{\mathrm{HH}}=8.0 \mathrm{~Hz},-\mathrm{CH}\right.$ Ar), 4.53 (s, 4H, -CH Fc), 4.48 (s, 4H, - CH Fc), 4.26 (s, 4H, - CH Fc), $4.21(\mathrm{~s}, 4 \mathrm{H},-\mathrm{CH} \mathrm{Fc}), 3.92(\mathrm{~s}, 10 \mathrm{H},-\mathrm{CH} \mathrm{Fc}), 3.91(\mathrm{~s}, 10 \mathrm{H}$, $-\mathrm{CH} \mathrm{Fc}) .{ }^{13} \mathrm{C}\left\{{ }^{1} \mathrm{H}\right\} \mathrm{NMR}(150.6 \mathrm{MHz})\left(\mathrm{CDCl}_{3}, 20{ }^{\circ} \mathrm{C}\right) \delta$ : 157.98 (4C, -CH Ar), 156.05 (2C, -CH Ar), 142.42 (2C, quat $\mathrm{Ar}), 141.48$ (2C, quat $\mathrm{Ar}), 137.48$ (2C, quat $\mathrm{Ar}), 136.85$ (2C, quat $\mathrm{Ar}$ ), 136.68 (2C, quat $\mathrm{Ar}), 136.04$ (2C, quat $\mathrm{Ar}), 133.90$ (2C, quat $\mathrm{Ar}$ ), 133.06 (2C, quat $\mathrm{Ar}), 131.18$ (4C, $-\mathrm{CH} \mathrm{Ar}$ ), 131.08 (4C, $-\mathrm{CH}$ Ar), 124.68 (4C, $-\mathrm{CH}$ Ar), 124.21 (4C, $-\mathrm{CH}$ $\mathrm{Ar}), 84.23$ (2C, quat Fc), 83.61 (2C, quat Fc), $69.74(10 \mathrm{C},-\mathrm{CH}$ $\mathrm{Fc}), 69.69$ (10C, -CH Fc), 69.00 (4C, $-\mathrm{CH} \mathrm{Fc}), 66.12$ (4C, $-\mathrm{CH}$ Fc), 66.02 (4C, $-\mathrm{CH}$ Fc), 60.05 (4C, $-\mathrm{CH}$ Fc). MALDI-TOF MS for $\mathrm{C}_{78} \mathrm{H}_{58} \mathrm{Fe}_{4} \mathrm{~N}_{4}$ : $[\mathrm{M}]^{+}$calculated $\mathrm{m} / \mathrm{z}$ 1274.2059, found $\mathrm{m} / \mathrm{z}$ 1274.2003. IR vbar $\left(\mathrm{cm}^{-1}\right): v(\mathrm{C}-\mathrm{H}$ st, aromatic): 3093, 3024, $v(\mathrm{C}=\mathrm{C}$ st $): 1608, v(\mathrm{C}=\mathrm{N}$ st $): 1548,1529, v(\mathrm{C}-\mathrm{H}$ rock $\mathrm{Fc})$ : 1104, 1082, 1049, 1019. Anal. Calcd for $\mathrm{C}_{78} \mathrm{H}_{58} \mathrm{Fe}_{4} \mathrm{~N}_{4} \cdot \frac{1}{2} \mathrm{CH}_{3} \mathrm{OH}$ : C, 73.20; H, 4.65; N, 4.36. Found: C, 73.17; H, 4.67; N, 4.40.

\section{Compound 11}

Cyclopentadienone 9 ( $0.4 \mathrm{~g}, 0.46 \mathrm{mmol})$, dipyrimidyl acetylene $(0.075 \mathrm{~g}, 0.41 \mathrm{mmol})$ and benzophenone $(1.5 \mathrm{~g})$ were mixed in a round bottomed flask and attached to an air condenser. The mixture was heated at $200{ }^{\circ} \mathrm{C}$ for $18 \mathrm{~h}$. The mixture was then subjected to flash column chromatography on silica. Eluting with dichloromethane removed all the benzophenone and any un-reacted cyclopentadienone. Elution with diethyl ether-methanol $(9: 1)$ and removal of the solvents in vacuo yielded the desired product as an orange powder $(0.24 \mathrm{~g}, 58 \%)$ mpt: $>200{ }^{\circ} \mathrm{C}$ (decomp.). ${ }^{1} \mathrm{H} \mathrm{NMR}\left(\mathrm{CDCl}_{3}, 20^{\circ} \mathrm{C}\right): \delta 8.86(\mathrm{~s}, 2 \mathrm{H}$, $-\mathrm{CH}$ Ar), 8.33 (s, 4H, - CH Ar), 7.05 (d, 4H, ${ }^{3} J_{\mathrm{HH}}=8.0 \mathrm{~Hz}$, $-\mathrm{CH}$ Ar), $6.80\left(\mathrm{~d}, 4 \mathrm{H},{ }^{3} J_{\mathrm{HH}}=8.0 \mathrm{~Hz},-\mathrm{CH}\right.$ Ar), $6.05(\mathrm{~m}, 6 \mathrm{H}$, - $\mathrm{CH}$ Ar), 4.55 (s, 4H, -CH Fc), 4.26 (s, 4H, -CH Fc), 3.89 (s, $10 \mathrm{H},-\mathrm{CH} \mathrm{Fc}), 3.52\left(\mathrm{~s}, 12 \mathrm{H},-\mathrm{OCH}_{3}\right) .{ }^{13} \mathrm{C}\left\{{ }^{1} \mathrm{H}\right\} \quad \mathrm{NMR}$ $(600 \mathrm{MHz})\left(\mathrm{CDCl}_{3}, 20^{\circ} \mathrm{C}\right): \delta 159.87$ (4C, quat $\left.\mathrm{Ar}\right), 157.68(4 \mathrm{C}$, - $\mathrm{CH} \mathrm{Ar}$ ), 156.09 (2C, quat Ar), 142.40 (2C, quat Ar), 141.34 (2C, quat $\mathrm{Ar}$ ), 140.21 (2C, quat $\mathrm{Ar}), 136.77$ (2C, quat $\mathrm{Ar}$ ), 136.68 (2C, quat $\mathrm{Ar}), 133.73$ (2C, quat $\mathrm{Ar}), 132.62$ (2C, $-\mathrm{CH}$ Ar), 130.57 (4C, -CH Ar), 124.15 (4C, -CH Ar), 109.85 (4C, - $\mathrm{CH}$ Ar), 98.51 (2C, -CH Ar), 84.36 (2C, quat Fc), 69.81 (10C, - $\mathrm{CH} \mathrm{Fc}$ ), 69.12 (4C, - CH Fc), 66.05 (4C, - CH Fc), 55.03 (4C, $-\mathrm{OCH}_{3}$ ). MALDI-TOF MS; for $\mathrm{C}_{62} \mathrm{H}_{50} \mathrm{Fe}_{2} \mathrm{~N}_{4} \mathrm{O}_{4}$ : [M] $]^{+}$calculated $\mathrm{m} / \mathrm{z}$ 1026.2531, found $\mathrm{m} / \mathrm{z}$ 1026.2560. IR $\operatorname{vbar}\left(\mathrm{cm}^{-1}\right)$ : $v(\mathrm{C}-\mathrm{H}$ st, aromatic $): 3024,2939, v\left(\mathrm{C}-\mathrm{H}\right.$ st, $\left.-\mathrm{OCH}_{3}\right): 2837$, $v(\mathrm{C}=\mathrm{C} \mathrm{st}): 1607, v(\mathrm{C}=\mathrm{N}$ st $): 1603,1550, v\left(\mathrm{C}-\mathrm{O}\right.$ st, $\left.-\mathrm{OCH}_{3}\right)$ : $1279, v(\mathrm{C}-\mathrm{H}$ rock Fc $): 1200,1161,1136$. Anal. Calcd for $\mathrm{C}_{62} \mathrm{H}_{50} \mathrm{Fe}_{2} \mathrm{~N}_{4} \mathrm{O}_{4}$ : C, 72.52; H, 4.91; N, 5.46. Found: C, 72.70; $\mathrm{H}, 4.71 ; \mathrm{N}, 5.24$.

\section{Compound 12}

1,2-Bis ( $p$-ferrocenylphenyl)acetylene (0.15 g, $0.27 \mathrm{mmol}), 9$ $(0.30 \mathrm{~g}, 0.34 \mathrm{mmol})$ and benzophenone $(2 \mathrm{~g})$ were mixed in a round bottomed flask and attached to an air condenser. The mixture was heated at $190{ }^{\circ} \mathrm{C}$ for $24 \mathrm{~h}$. The mixture was then subjected to flash column chromatography on silica. Eluting with dichloromethane followed by recrystallisation from hexane yielded the desired product as an orange-red powder $(0.07 \mathrm{~g}$, 18\%). mpt: $>200{ }^{\circ} \mathrm{C}$ (decomp.). ${ }^{1} \mathrm{H}$ NMR $\left(\mathrm{C}_{2} \mathrm{D}_{2} \mathrm{Cl}_{4}, 60{ }^{\circ} \mathrm{C}\right)$ : $\delta 7.06\left(\mathrm{~d}, 8 \mathrm{H},{ }^{3} J_{\mathrm{HH}}=8.0 \mathrm{~Hz},-\mathrm{CH} \mathrm{Ar}\right), 6.83\left(\mathrm{~d}, 8 \mathrm{H},{ }^{3} J_{\mathrm{HH}}=\right.$ $8.0 \mathrm{~Hz},-\mathrm{CH} \mathrm{Ar}), 6.14\left(\mathrm{~d}, 4 \mathrm{H},{ }^{4} J_{\mathrm{HH}}=2.0 \mathrm{~Hz},-\mathrm{CH} \mathrm{Ar}\right), 6.02(\mathrm{t}$, $\left.2 \mathrm{H},{ }^{4} J_{\mathrm{HH}}=2.0 \mathrm{~Hz},-\mathrm{CH} \mathrm{Ar}\right), 4.54(\mathrm{~s}, 8 \mathrm{H},-\mathrm{CH} \mathrm{Fc}), 4.23(\mathrm{~s}, 8 \mathrm{H}$, $-\mathrm{CH} \mathrm{Fc}), 3.91(\mathrm{~s}, 20 \mathrm{H},-\mathrm{CH} \mathrm{Fc}), 3.48\left(\mathrm{~s}, 12 \mathrm{H},-\mathrm{OCH}_{3}\right)$. ${ }^{13} \mathrm{C}\left\{{ }^{1} \mathrm{H}\right\} \operatorname{NMR}(150.6 \mathrm{MHz})\left(\mathrm{CDCl}_{3}, 20{ }^{\circ} \mathrm{C}\right) \delta: 159.23(4 \mathrm{C}$, quat $\mathrm{Ar}$ ), 142.42 (2C, quat $\mathrm{Ar}$ ), 140.13 (2C, quat $\mathrm{Ar}$ ), 139.91 (4C, quat $\mathrm{Ar}$ ), 138.44 (2C, quat $\mathrm{Ar}$ ), 136.06 (4C, quat $\mathrm{Ar}$ ), 130.97 (8C, - CH Ar), 123.89 (8C, - CH Ar), 110.09 (4C, - $\mathrm{CH}$ Ar), 97.57 (2C, $-\mathrm{CH} \mathrm{Ar}), 70.17$ (8C, $-\mathrm{CH} \mathrm{Fc}), 69.30$ (4C, quat Fc), 66.19 (8C, $-\mathrm{CH} \mathrm{Fc}), 54.87\left(24 \mathrm{C},-\mathrm{CH} \mathrm{Fc} \&-\mathrm{OCH}_{3}\right)$. MALDI-TOF MS for $\mathrm{C}_{86} \mathrm{H}_{70} \mathrm{Fe}_{4} \mathrm{O}_{4}:[\mathrm{M}]^{+}$calculated $\mathrm{m} / \mathrm{z}$ 1390.2672 , found $\mathrm{m} / z$ 1390.2739. IR $v$ bar $\left(\mathrm{cm}^{-1}\right): v(\mathrm{C}-\mathrm{H}$ st, aromatic): 3088, 3020, $v\left(\mathrm{C}-\mathrm{H}\right.$ st, $\left.-\mathrm{OCH}_{3}\right): 2952,2833, v(\mathrm{C}=\mathrm{C} \mathrm{st})$ : $1606,1562,1529, v\left(\mathrm{C}-\mathrm{O}\right.$ st, $\left.-\mathrm{OCH}_{3}\right): 1274, v(\mathrm{C}-\mathrm{H}$ rock $\mathrm{Fc})$ : 1158, 1104, 1062. Anal. Calcd for $\mathrm{C}_{86} \mathrm{H}_{70} \mathrm{Fe}_{4} \mathrm{O}_{4}$ : C, 74.27; $\mathrm{H}$, 5.07. Found: C, 74.04; H, 4.83.

\section{Iodo-HBC}

A solution of iron(III) chloride (1.8 g, $14.0 \mathrm{mmol})$ in nitromethane $(3 \mathrm{~mL})$ was added dropwise to a stirred solution of the uncyclised iodo-polyphenylene precursor $(0.35 \mathrm{~g}, 0.47 \mathrm{mmol})$ in dichloromethane $(40 \mathrm{~mL})$. An argon stream was bubbled through the reaction mixture throughout the entire reaction. After stirring for $45 \mathrm{~min}$ the reaction was quenched with methanol $(40 \mathrm{~mL})$. The precipitate was filtered, washed with methanol $(100 \mathrm{~mL})$ and dried under reduced pressure. The crude product was purified by column chromatography on silica, elution with hexane-dichloromethane $(4: 1)$ and removal of the solvents yielded the desired product as an off-white crystalline solid (0.30 g, 85\%). mpt: $>300{ }^{\circ} \mathrm{C} .{ }^{1} \mathrm{H} \mathrm{NMR}\left(\mathrm{CDCl}_{3}, 20{ }^{\circ} \mathrm{C}\right) \delta: 9.20$ (s, 2H, -CH Ar), 9.15 (s, 2H, -CH Ar), 9.07 (s, 2H, -CH Ar), 8.96 (s, 2H, -CH Ar), 8.86 (s, 2H, - CH Ar), 8.69 (s, 2H, - CH Ar), $1.95\left(\mathrm{~s}, 9 \mathrm{H},-\mathrm{C}\left(\mathrm{CH}_{3}\right)_{3}\right), 1.91\left(\mathrm{~s}, 18 \mathrm{H},-\mathrm{C}\left(\mathrm{CH}_{3}\right)_{3}\right), 1.82$ $\left(\mathrm{s}, 18 \mathrm{H},-\mathrm{C}\left(\mathrm{CH}_{3}\right)_{3}\right) \cdot{ }^{13} \mathrm{C}\left\{{ }^{1} \mathrm{H}\right\} \mathrm{NMR}\left(\mathrm{CDCl}_{3}, 20{ }^{\circ} \mathrm{C}\right): \delta 148.56$ (quat $\mathrm{Ar}$ ), 148.40 (quat $\mathrm{Ar}$ ), 148.37 (quat $\mathrm{Ar}$ ), 131.97 (quat $\mathrm{Ar}$ ), 130.17 (quat $\mathrm{Ar}$ ), 129.92 (quat $\mathrm{Ar}$ ), 129.84 (quat $\mathrm{Ar}$ ), 129.68 (quat $\mathrm{Ar}$ ), 129.61 (2C,-CH Ar), 128.23 (quat $\mathrm{Ar}$ ), 124.06 (quat $\mathrm{Ar}$ ), 123.25 (quat $\mathrm{Ar}$ ), 123.21 (quat $\mathrm{Ar}$ ), 123.09 (quat $\mathrm{Ar}$ ), 120.22 (quat $\mathrm{Ar}$ ), 119.83 (quat $\mathrm{Ar}$ ), 119.72 (quat $\mathrm{Ar}$ ), 118.95 (quat $\mathrm{Ar}$ ), 118.88 (2C, $-\mathrm{CH} \mathrm{Ar}), 118.85$ (2C, $-\mathrm{CH} \mathrm{Ar}), 118.58$ (2C, $-\mathrm{CH} \mathrm{Ar}), 118.54$ (2C, $-\mathrm{CH} \mathrm{Ar}), 118.48$ (2C, $-\mathrm{CH} \mathrm{Ar})$, $35.65\left(1 \mathrm{C}\right.$, quat $\left.-\mathrm{C}\left(\mathrm{CH}_{3}\right)_{3}\right), 35.59\left(2 \mathrm{C}\right.$, quat $\left.-\mathrm{C}\left(\mathrm{CH}_{3}\right)_{3}\right), 35.52$ $\left(2 \mathrm{C}\right.$, quat $\left.-\mathbf{C}\left(\mathrm{CH}_{3}\right)_{3}\right), 32.01\left(3 \mathrm{C},-\mathrm{CH},-\mathrm{C}\left(\mathrm{CH}_{3}\right)_{3}\right), 31.98(6 \mathrm{C}$, $\left.-\mathrm{CH},-\mathrm{C}\left(\mathrm{CH}_{3}\right)_{3}\right), 31.93\left(6 \mathrm{C},-\mathrm{CH},-\mathrm{C}\left(\mathbf{C H}_{3}\right)_{3}\right)$. MALDI-TOF MS calculated for $\mathrm{C}_{62} \mathrm{H}_{57} \mathrm{I}:[\mathrm{M}]^{+}$calculated $\mathrm{m} / \mathrm{z} 928.3505$, found $\mathrm{m} / z$ 928.3549. IR $v$ bar $\left(\mathrm{cm}^{-1}\right): v(\mathrm{C}-\mathrm{H}$ st, aromatic): 3099 , $v\left(\mathrm{C}-\mathrm{H}\right.$ st, $\left.-\mathrm{CH}_{3}\right)$ : 2953, 2902, 2866. Anal. Calcd for $\mathrm{C}_{62} \mathrm{H}_{57} \mathrm{I}$ : C, 80.16; H, 6.18. Found: C, 79.92; H, 6.03.

\section{Compound 13}

Ethynylferrocene $(0.027 \mathrm{~g}, 0.13 \mathrm{mmol})$ was dissolved in triethylamine $(3 \mathrm{~mL})$ and added via cannula to a solution of iodo-HBC $(0.1 \mathrm{~g}, 0.11 \mathrm{mmol})$ and tetrakis(triphenylphosphino)palladium 
$(0.006 \mathrm{~g}, 0.006 \mathrm{mmol})$ in toluene $(8 \mathrm{~mL})$. The mixture was heated at $70{ }^{\circ} \mathrm{C}$ for $18 \mathrm{~h}$. The solvents were removed in vacuo, washed with water and extracted into dichloromethane. The organic phase was dried over $\mathrm{MgSO}_{4}$, solvents removed in vacuo again before being subjected to column chromatography on silica. Elution with hexane-dichloromethane $(1: 1)$ followed by recrystallisation from methanol yielded the desired product as a fine orange-red powder $(0.08 \mathrm{~g}, 77 \%)$. mpt: $>200{ }^{\circ} \mathrm{C}$ (decomp.). ${ }^{1} \mathrm{H}$ NMR $(600.1 \mathrm{MHz})\left(\mathrm{CDCl}_{3}, 20{ }^{\circ} \mathrm{C}\right)$ : $\delta 9.24$ (s, 2H, $-\mathrm{CH}$ Ar), 9.18 (s, 2H, $-\mathrm{CH}$ Ar), 9.13 (s, $2 \mathrm{H},-\mathrm{CH}$ Ar), 9.04 (s, 2H, - CH Ar), 8.91 (s, 2H, - CH Ar), 8.81 (s, 2H, - $\mathrm{CH} \mathrm{Ar}$ ), 4.85 (s, 2H, - CH Fc), 4.50 (s, 5H, - CH Fc), 4.46 (s, $2 \mathrm{H},-\mathrm{CH} \mathrm{Fc}), 1.98$ (s, 9H, $\left.-\mathrm{C}\left(\mathrm{CH}_{3}\right)_{3}\right), 1.95\left(\mathrm{~s}, 18 \mathrm{H},-\mathrm{C}\left(\mathrm{CH}_{3}\right)_{3}\right)$, 1.89 (s, $\left.18 \mathrm{H},-\mathrm{C}\left(\mathrm{CH}_{3}\right)_{3}\right) .{ }^{13} \mathrm{C}\left\{{ }^{1} \mathrm{H}\right\} \mathrm{NMR}(150.6 \mathrm{MHz})\left(\mathrm{CDCl}_{3}\right.$, $20^{\circ} \mathrm{C}$ ): $\delta 148.72$ (quat $\mathrm{Ar}$ ), 148.69 (quat $\mathrm{Ar}$ ), 148.61 (quat $\mathrm{Ar}$ ), 130.49 (quat $\mathrm{Ar}$ ), 130.31 (quat $\mathrm{Ar}$ ), 130.14 (quat $\mathrm{Ar}$ ), 130.10 (quat $\mathrm{Ar}$ ), 129.98 (quat $\mathrm{Ar}$ ), 129.28 (quat $\mathrm{Ar}$ ), 124.80 (quat $\mathrm{Ar}$ ), $124.21(2 \mathrm{C},-\mathrm{CH} \mathrm{Ar}$ ), 123.52 (quat $\mathrm{Ar}$ ), 123.49 (quat $\mathrm{Ar}$ ), 123.47 (quat $\mathrm{Ar}$ ), 121.46 (quat $\mathrm{Ar}$ ), 120.47 (quat $\mathrm{Ar}$ ), 120.30 (quat $\mathrm{Ar}$ ), 120.12 (quat $\mathrm{Ar}$ ), 119.59 (quat $\mathrm{Ar}$ ), $119.32(2 \mathrm{C},-\mathrm{CH}$ Ar), 118.99 (2C, $-\mathrm{CH} \mathrm{Ar}), 118.83$ (2C, $-\mathrm{CH} \mathrm{Ar}), 118.80$ (2C, - $\mathrm{CH} \mathrm{Ar}$ ), 118.78 (2C, $-\mathrm{CH} \mathrm{Ar}), 91.50$ (1C, quat Fc), 89.21 (1C, $-\mathrm{C} \equiv \mathrm{C}-), 87.39(1 \mathrm{C},-\mathrm{C} \equiv \mathrm{C}-), 71.51(2 \mathrm{C},-\mathrm{CH} \mathrm{Fc}), 69.98$ (5C, $-\mathrm{CH} \mathrm{Fc}), 68.93(2 \mathrm{C},-\mathrm{CH} \mathrm{Fc}), 35.62$ (3C, quat, $\left.-\mathbf{C}\left(\mathrm{CH}_{3}\right)_{3}\right)$, 35.59 (2C, quat, $\left.-\mathbf{C}\left(\mathrm{CH}_{3}\right)_{3}\right), 31.98\left(6 \mathrm{C},-\mathrm{CH},-\mathrm{C}\left(\mathbf{C H}_{3}\right)_{3}\right), 31.94$ (9C, $\left.-\mathrm{CH},-\mathrm{C}\left(\mathbf{C H}_{3}\right)_{3}\right)$. MALDI-TOF MS for $\mathrm{C}_{74} \mathrm{H}_{66} \mathrm{Fe}$ : $[\mathrm{M}]^{+}$ calculated $\mathrm{m} / \mathrm{z}$ 1010.4514, found $\mathrm{m} / \mathrm{z} 1010.4509$. IR $v\left(\mathrm{~cm}^{-1}\right)$ : $v\left(\mathrm{C}-\mathrm{H}\right.$ st, aromatic): $3099, v\left(\mathrm{C}-\mathrm{H}\right.$ st, $\left.-\mathrm{CH}_{3}\right): 2954,2904,2666$, $v(\mathrm{C} \equiv \mathrm{C}$ st $): 2200 v(\mathrm{C}=\mathrm{C}$ st $): 1606,1578, v(\mathrm{C}-\mathrm{H}$ rock $\mathrm{Fc}):$ $1090,1055$.

\section{NLO measurements}

The harmonic light scattering (HLS) technique involves the detection of the incoherently scattered second harmonic generated by a solution of the molecule under irradiation with a laser of wavelength $\lambda$, leading to the measurement of the mean value of the $\beta \times \beta$ tensor product, $<\beta_{\mathrm{HLS}}>$. The square root of this value is quoted as $\beta$. In the present work, $\beta$ measurements have been made using $\lambda=1.91 \mu \mathrm{m}$ as the fundamental wavelength. As the harmonic wavelength at $955 \mathrm{~nm}$ is far away from the 2-photon resonance, any contribution from 2-photon fluorescence to the HLS signal is negligible. The $1.91 \mu \mathrm{m}$ fundamental beam is emitted by a high-pressure hydrogen (30 bars) Raman cell $(l=50 \mathrm{~cm})$, pumped by a $\mathrm{Nd}^{3+}$ : YAG laser operating at $1.06 \mu \mathrm{m}$ and providing a $10 \mathrm{~Hz}$ repetition rate with $15 \mathrm{~ns}$ duration pulses.

Our reference sample is a concentrated $\left(5 \times 10^{-3} \mathrm{~mol} \mathrm{~L}^{-1}\right)$ solution of Crystal Violet. Its octupolar $\beta$ value is $170 \times 10^{-30}$ esu at $1.91 \mu \mathrm{m}$. It must be noted that most classical organic solvents are not transparent at $1.9 \mu \mathrm{m}$. Chloroform is the most suitable standard solvent in this wavelength range. It can be used in a fluorescence cell $(l=1 \mathrm{~cm})$ in order to minimise propagation losses over the typical $0.5 \mathrm{~cm}$ actual interaction length within the solution. HRS photons emitted at $955 \mathrm{~nm}$ are collected at a $90^{\circ}$ angle with respect to the direction of the incident beam, and are focused onto a PMT using two collecting lenses. The detected signal is then sampled and averaged using a Boxcar and processed by a computer. The reference beam is collected at a $45^{\circ}$ incidence angle by a glass plate and focused onto a highly nonlinear NPP (N-4-nitrophenyl-prolinol) powder used as a frequency doubler. The variation of the scattered second harmonic intensity from the solution is recorded on the computer as a function of the reference second harmonic signal provided by the NPP powder. $\beta$ values are then inferred from the slopes of the resulting lines. The relative experimental error for $\beta$ values is $\leq 10 \%$.

\section{Acknowledgements}

We thank Dr John O'Brien and Dr Martin Feeney for technical assistance. The work was financially supported by Science Foundation Ireland (05 PICA-I819, SFI-08RFPCHE1465 and STTF).

\section{Notes and references}

1 I. R. Butler, S. Mussig and M. Plath, Inorg. Chem. Commun., 1999, 2, 424-427.

2 N. J. Long, Angew. Chem., Int. Ed. Engl., 1995, 34, 21-38.

3 J. D. McKinney, P. A. Anderson, T. A. Hamor, C. J. Jones, K. Paxton and A. Porch, J. Organomet. Chem., 1998, 558, 147-153.

4 M. Laskoski, G. Roidl, M. D. Smith and U. H. F. Bunz, Angew. Chem., Int. Ed., 2001, 40, 1460-1463.

5 M. Laskoski, J. G. M. Morton, M. D. Smith and U. H. F. Bunz, J. Organomet. Chem., 2002, 652, 21-30.

6 M. Laskoski, W. Steffen, M. D. Smith and U. H. F. Bunz, Chem. Commun., 2001, 691-692.

7 P. T. Herwig, V. Enkelmann, O. Schmelz and K. Müllen, Chem.-Eur. J., 2000, 6, 1834-1839.

8 A. Woolf, A. B. Chaplin, J. E. McGrady, M. A. M. Alibadi, N. Rees, S. Draper, F. Murphy and A. S. Weller, Eur. J. Inorg. Chem., 2011, $1614-1625$.

9 D. Nolan, B. Gil, F. A. Murphy and S. M. Draper, Eur. J. Inorg. Chem., 2011, 21, 3248-3256.

10 D. J. Roberts, D. J. Gregg, C. M. Fitchett and S. M. Draper, Organometallics, 2010, 29, 6541-6547.

11 P. Stepnicka, L. Trojan, J. Kubista and J. Ludvik, J. Organomet. Chem., 2001, 637, 291-299.

12 A. J. Moore, A. Chesney, M. R. Bryce, A. S. Batsanov, J. F. Kelly, J. A. K. Howard, I. F. Perepichka, D. F. Perepichka, G. Meshulam, G. Berkovic, Z. Kotler, R. Mazor and V. Khodorkovsky, Eur. J. Org. Chem., 2001, 14, 2671-2687.

13 A. K. Diallo, J. C. Daran, F. Varret, J. Ruiz and D. Astruc, Angew. Chem., Int. Ed., 2009, 48, 3141-3145.

14 X. Dou, X. Y. Yang, G. J. Bodwell, M. Wagner, V. Enkelmann and K. Müllen, Org. Lett., 2007, 9, 2485-2488.

15 X. L. Feng, W. Pisula, M. Takase, X. Dou, V. Enkelmann, M. Wagner, N. Ding and K. Müllen, Chem. Mater., 2008, 20, 2872-2874.

16 B. J. Coe, C. J. Jones, J. A. McCleverty, D. Bloor and G. Cross, J. Organomet. Chem., 1994, 464, 225-232.

17 V. J. Chebny, D. Dhar, S. V. Lindeman and R. Rathore, Org. Lett., 2006, 8, 5041-5044.

18 S. Ito, M. Wehmeier, J. D. Brand, C. Kübel, R. Epsch, J. P. Rabe and K. Müllen, Chem.-Eur. J., 2000, 6, 4327-4342.

19 X. Don, W. Pisula, J. Wu, G. J. Bodwell and K. Müllen, Chem.-Eur. J., 2008, 14, 240-249.

20 F. A. Murphy and S. M. Draper, J. Org. Chem., 2010, 75, 1862-1870.

21 S. K. Burley and G. A. Petsko, Adv. Protein Chem., 1988, 39, 125-189.

22 G. R. Desiraju and A. Gavezzotti, J. Chem. Soc., Chem. Commun., 1989, 621-623.

23 G. R. Desiraju and A. Gavezzotti, Acta Crystallogr., Sect. B: Struct. Sci., 1989, 45, 473-482.

24 C. A. Hunter and J. K. M. Sanders, J. Am. Chem. Soc., 1990, 112, $5525-5534$.

25 R. Foster, Organic Charge-Transfer Complexes, Academic Press, London, 1969. 
26 A. V. Muehldorf, D. Vanengen, J. C. Warner and A. D. Hamilton, J. Am Chem. Soc., 1988, 110, 6561-6562.

27 P. Hobza, H. L. Selzle and E. W. Schlag, J. Am. Chem. Soc., 1994, 116, 3500-3506.

28 A. S. Shetty, J. S. Zhang and J. S. Moore, J. Am. Chem. Soc., 1996, 118, 1019-1027.

29 J. C. Calabrese, L. T. Cheng, J. C. Green, S. R. Marder and W. Tam, J. Am. Chem. Soc., 1991, 113, 7227-7232.

30 K. N. Jayaprakash, P. C. Ray, I. Matsuoka, M. M. Bhadbhade, V. G. Puranik, P. K. Das, H. Nishihara and A. Sarkar, Organometallics, $1999,18,3851-3858$.

31 K. R. J. Thomas and J. T. Lin, J. Organomet. Chem., 2001, 637, 139-144.

32 M. J. Frisch, G. W. Trucks, H. B. Schlegel, G. E. Scuseria, M. A. Robb, J. R. Cheeseman, G. Scalmani, V. Barone, B. Mennucci, G. A. Petersson, H. Nakatsuji, M. Caricato, X. Li, H. P. Hratchian, A. F. Izmaylov, J. Bloino, G. Zheng, J. L. Sonnenberg, M. Hada, M. Ehara, K. Toyota, R. Fukuda, J. Hasegawa, M. Ishida, T. Nakajima, Y. Honda, O. Kitao, H. Nakai, T. Vreven, J. A. Montgomery, Jr., J. E. Peralta, F. Ogliaro,
M. Bearpark, J. J. Heyd, E. Brothers, K. N. Kudin, V. N. Staroverov, R. Kobayashi, J. Normand, K. Raghavachari, A. Rendell, J. C. Burant, S. S. Iyengar, J. Tomasi, M. Cossi, N. Rega, J. M. Millam, M. Klene, J. E. Knox, J. B. Cross, V. Bakken, C. Adamo, J. Jaramillo, R. Gomperts, R. E. Stratmann, O. Yazyev, A. J. Austin, R. Cammi, C. Pomelli, J. Ochterski, R. L. Martin, K. Morokuma, V. G. Zakrzewski, G. A. Voth, P. Salvador, J. J. Dannenberg, S. Dapprich, A. D. Daniels, O. Farkas, J. B. Foresman, J. V. Ortiz, J. Cioslowski and D. J. Fox, GAUSSIAN 09 (Revision A.1), Gaussian, Inc., Wallingford, CT, 2009.

33 Y. Zhao and D. G. Truhlar, Acc. Chem. Res., 2008, 41, 157-167.

34 N. Tsuboya, R. Hamasaki, M. Ito, M. Mitsuishi, T. Miyashita and Y. Yamamoto, J. Mater. Chem., 2003, 13, 511-513.

35 P. D. Maker, Phys. Rev. A: At., Mol., Opt. Phys., 1970, 1, 923-951.

36 K. Clays and A. Persoons, Phys. Rev. Lett., 1991, 66, 2980-2983.

37 J. Zyss and I. Ledoux, Chem. Rev., 1994, 94, 77-105.

38 M. Rosenblum, N. Brawn, J. Papenmeier and M. Applebaum, J. Organomet. Chem., 1966, 6, 173-180.

39 D. J. Gregg, E. Bothe, P. Hofer, P. Passaniti and S. M. Draper, Inorg. Chem., 2005, 44, 5654-5660. 